Utah State University

DigitalCommons@USU

\title{
Preliminary Classification for the Coniferous Forest and Woodland Series of Arizona and New Mexico
}

\author{
Earle F. Layser \\ Gilbert H. Schubert
}

Follow this and additional works at: https://digitalcommons.usu.edu/aspen_bib

Part of the Agriculture Commons, Ecology and Evolutionary Biology Commons, Forest Sciences Commons, Genetics and Genomics Commons, and the Plant Sciences Commons

\section{Recommended Citation}

Layser, Earle F. and Schubert, Gilbert H. 1979. Preliminary classification for the coniferous forest and woodland series of Arizona and New Mexico. Forest Service. Research Paper RM-208. Rocky Mountain Forest and Range Experiment Station, Fort Collins, CO

This Report is brought to you for free and open access by the Aspen Research at DigitalCommons@USU. It has been accepted for inclusion in Aspen Bibliography by an authorized administrator of DigitalCommons@USU. For more information, please contact

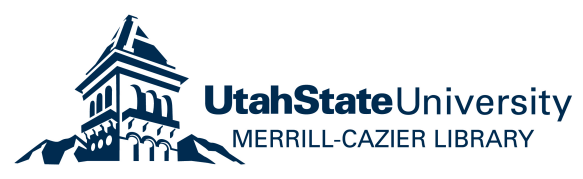




\title{
Preliminary Classification for the Coniferous Forest and Woodland Series of Arizona and New Mexico
}

\author{
Earle F. Layser, Resource Analyst ${ }^{1}$ \\ Southwest Region, USDA Forest Service \\ Gilbert H. Schubert, Principal Silviculturist ${ }^{2}$ \\ Rocky Mountain Forest and Range Experiment Station
}

${ }^{1}$ Now Assistant Forest Supervisor, Bridger-Teton National Forest, Jackson, Wyo.

2Schubert, now retired, was located at the Station's Research Work Unit located at Flagstaff, in cooperation with Northern Arizona University. Station's central headquarters is maintained at Fort Collins, in cooperation with Colorado State University. 


\section{Contents}

Page

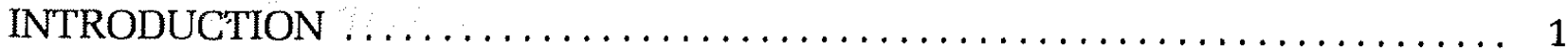

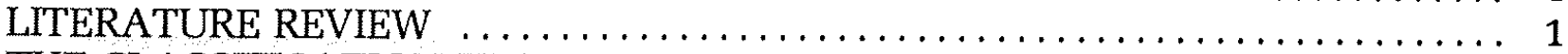

THE CLASSIFICATION FRAMEWORK, SYNECOLOGICAL

PERSPECTIVE, AND TERMINOLOGY $\ldots \ldots \ldots \ldots \ldots \ldots \ldots \ldots \ldots \ldots \ldots, 3$

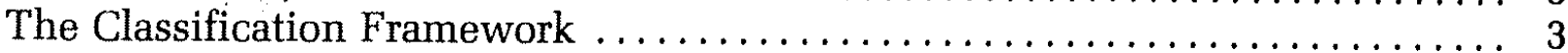

Synecological Perspective and Terminology ...................... 3

PRELIMINARY CLASSIFICATION OF CONIFEROUS FOREST

AND WOODLAND SERIES $\ldots \ldots \ldots \ldots \ldots \ldots \ldots \ldots \ldots \ldots \ldots \ldots \ldots, 9$

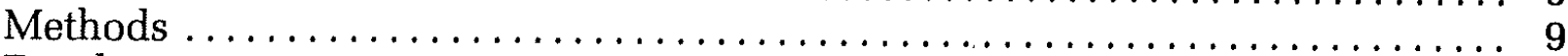

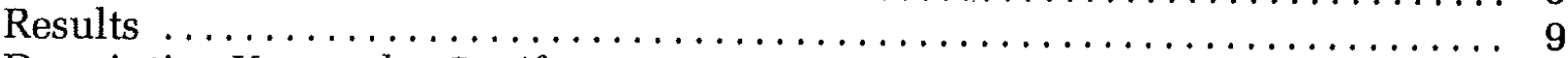

Descriptive Key to the Coniferous Forest

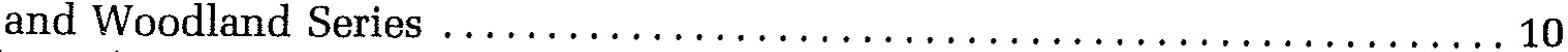

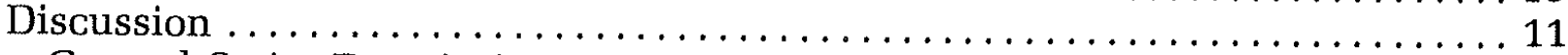

General Series Description $\ldots \ldots \ldots \ldots \ldots \ldots \ldots \ldots \ldots \ldots \ldots \ldots \ldots \ldots \ldots \ldots$

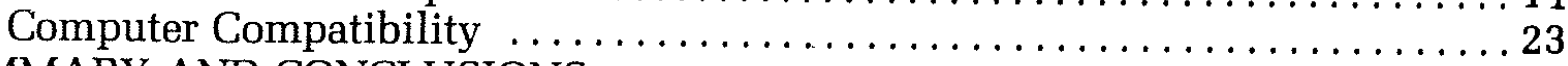

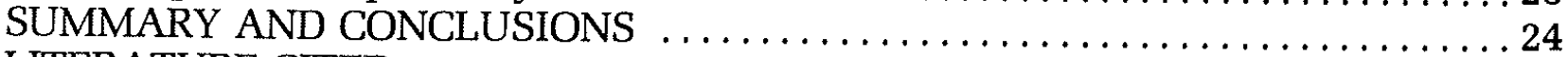

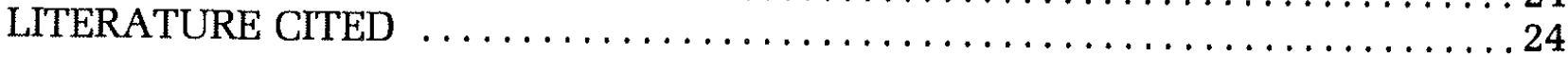




\title{
Preliminary Classification for the Coniferous Forest and Woodland Series of Arizona and New Mexico
}

\author{
Earle F. Layser and Gilbert H. Schubert
}

\section{INTRODUCTION}

The vegetation of southwestern United States, because of this geographic area's climatic patterns and extreme ranges in topographic relief, is complex and diverse. For purposes of land management and planning, a systematic classification and a uniform understanding and application of vegetation classification concepts are needed in the Southwest. The vegetation classification system must be applicable to project and prescription level planning, as well as to long range planning involving land classification systems ${ }^{3}$ and resource assessment under the Forest and Rangeland Resources Planning Act of 1974.

The ways vegetation classification can serve land management and research have been reviewed elsewhere (Daubenmire 1976, Layser 1974, Pfister 1976, Volland 1975). Classification can aid in communication about forest and rangelands, and can assist in greater understanding of ecological factors as they relate to management and site. The mappable hierarchial categories permit different levels of generalization, adding to the usefulness of the system for land management. Information on both existing and potential vegetation ${ }^{4}$ is necessary where management attempts to raise the productivity of a region to optimum and sustain it there, and where consideration of the dynamic as well as static features of vegetation is essential (fig. 1) (Kuchler 1967).

\footnotetext{
${ }^{3}$ Gallaher, W. B. Modified ECOCLASS report to Regional Foresters, Rocky Mountain and Southwestern Regions, USDA Forest Service, and Director, Rocky Mountain Forest and Range Experiment Station; 4040 Habitat Type Classification, January 31, 1977. Report contains recommendations dealing with staffing and research needs to implement Modified ECOCLASS.
}

\footnotetext{
${ }^{4}$ The term potential vegetation, as applied here, can refer to any, or collectively all, the classification levels (i.e., formation, series, association). The term relates to climax (Tansley 1935) potential as it exists today, not the possible vegetation responses resulting from management treatments.
}

\section{LITERATURE REVIEW}

The Southwest is a particularly good area to study plant ecology because of the insular nature of the mountain ranges and the abrupt differences in physiography and climate. Some of the earliest work (Merriam 1890, 1898) on bioclimatic classification in the United States was conducted in the Southwest. Other early students of plant ecology for the area included Hanson (1924), Korstian (1917), Pearson (1920), Shreve (1915), and Watson (1912).

While this partial review is directed primarily at the coniferous forest and woodland ${ }^{5}$ vegetation in the Southwest, it should be pointed out that considerable literature for the grassland, and scrubland vegetation also exists.

Shreve (1942) named and defined nine principal types of vegetation for Arizona based on altitude. Howell (1941), Kesek (1966), Merkle (1952), and Whiting (1942) studied and described facets of pinyon and juniper ecology in various parts of the Southwest. Lindsley (1951) described the forest vegetation at the Grants lava bed in New Mexico.

Nichol $(1937,1952)$ described and mapped natural vegetation of Arizona. In 1954, the Society of American Foresters published the Forest Cover Types of North America. Merkle (1954) analyzed the spruce-fir community on the Kaibab Plateau, Arizona. The vegetation of the Huachuca Mountains, Arizona, was described and mapped by Wallmo (1955). Castetter (1956) reported on the vegetation of the Manzano, Jemez, and Sandia Mountains, New Mexico. Changes in ponderosa pine forests in Arizona since white settlement have been characterized by Cooper (1960). Merkle

\footnotetext{
${ }^{5}$ Woodland is used in this paper as a category because of its general acceptance and application for describing certain vegetation in the Southwest. The definition (Brown and Lowe 1974) is incorporated into the key leads; FordRobertson (1971) also define woodlands in the sense it is used here. This is not to be confused with eastern United States, where "woodland" is sometimes used in forestry terminology to refer to any lands adapted to production of woodcrops.
} 
(1962) described some of the forest communities of the Grand Canyon area, Arizona. Little (1950, 1971, 1975, 1976) described the trees of the Southwest, their distributions, and associated forest species. In the 1950 publication, he also presented a map of the principal vegetation of Arizona and New Mexico.

In 1964, Kuchler prepared a map and accompanying manual of the potential natural vegetation of the conterminous United States. Lowe (1961, 1964) reviewed the literature and presented discussion of the life zones and biotic communities for Arizona. Gehlbach (1967) described the vegetation of the Guadalupe escarpment in New Mexico. The vegetation of the Organ Mountains, New Mexico, was treated by Dick-Peddie and Moir (1970); and Hanks and Dick-Peddie (1974) described forest succession in the White Mountains, New Mexico. Freeman and Dick-Peddie (1970) studied woody riparian vegetation in the Black and Sacramento Mountain Ranges of New Mexico.

The vegetation of the mountainous portions of Utah has been described in part by Dixon (1935), Ellison (1954), Pfister (1972), and Ream (1963). Brown (1973) described and mapped the vegetation of Arizona. Alexander (1974a, 1974b), Hanley et al: (1975), Jones (1974), and Schubert (1974) portrayed successional relationships of tree species in the southern Rockies.

Brown and Lowe (1974) have proposed a computer-compatible system for organizing and classifying natural and potential vegetation information. Their approach has merit for land management and planning purposes.

Turner (1974) prepared a general map and discussion for the vegetation of the Tucson area of Arizona. Whittaker and Niering (1975) described in detail the vegetation of the Santa Catalina

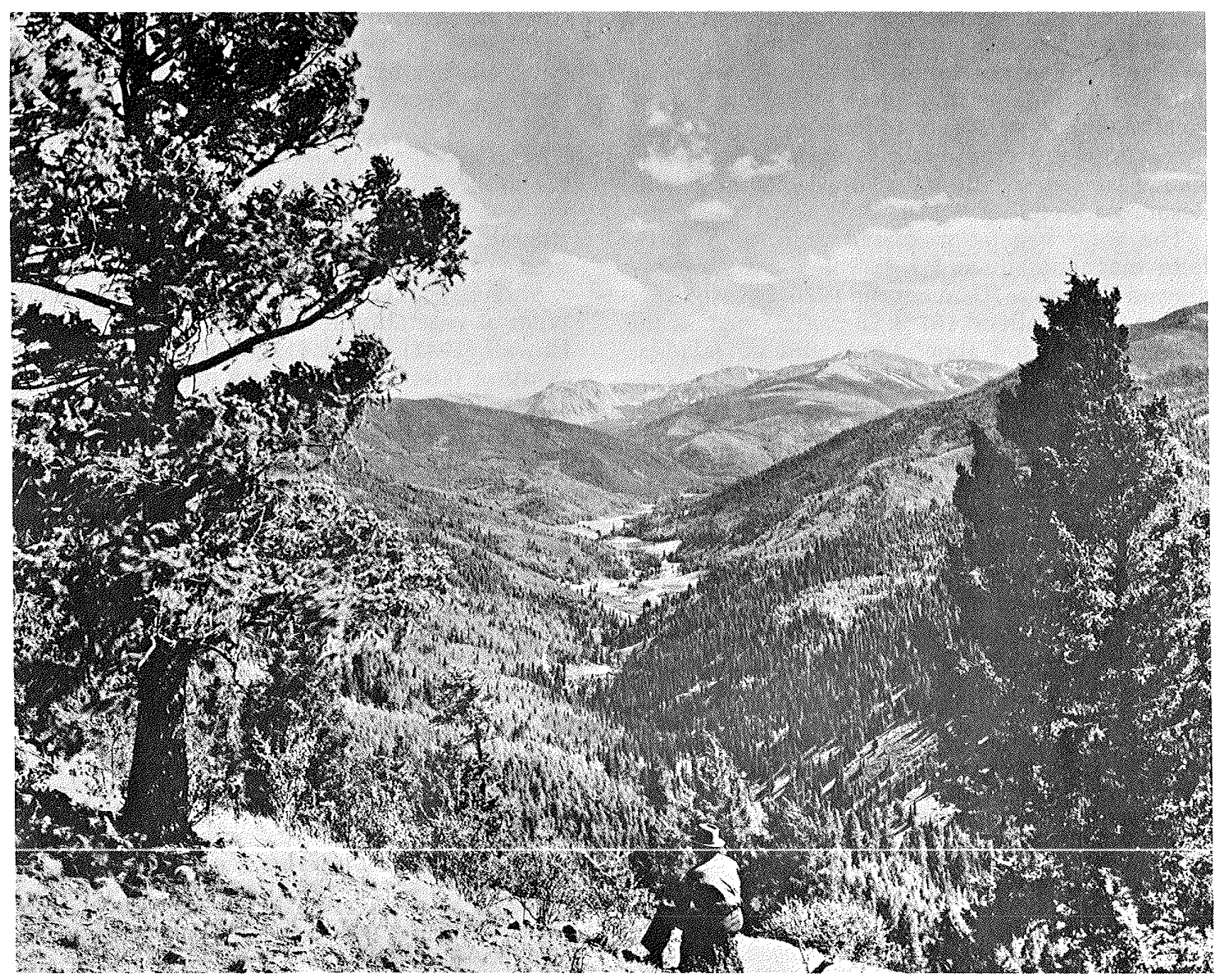

Figure 1.-Forest vegetation forms a mosaic pattern in mountainous terrain reflecting differences in habitat and in successional stages. Carson National Forest, New Mexico. 
Mountains, Arizona. Brown et al. (1977) published a map of biotic communities of the Southwest.

The USDA Forest Service contracted for vegetation classification studies with Moir and Ludwig (1977) on the spruce-fir and mixed conifer in New Mexico and Arizona; and with Hanks et al. (1977) for the ponderosa pine habitat types on the Colorado Plateau.

Much of the literature lacks quantitative data for rigorous comparison, and describes vegetation only in a general way which is useful for rough comparisons. In other cases, data in the literature are presented for gradient analyses, but not in the form of community analyses or sampling.

\section{THE CLASSIFICATION FRAMEWORK, SYNECOLOGICAL PERSPECTIVE, AND TERMINOLOGY}

Problems generally encountered in developing and utilizing a vegetative classification system are: (1) different ecologists may use the same terms differently; and (2) different authors may recognize different types for similar situations. This can cause confusion in relating different ecological works to a common system, especially for those unfamiliar with the terminology, concepts, or problem. This section provides clarification, and encourages uniform application of terms and concepts.

Recent, extensive adoption of the methods and applications for vegetation classification proposed here, have demonstrated the merit of this approach in land management and research (Daubenmire 1976, Pfister 1976). Continuity is desirable in classification of coniferous forest vegetation for the southern Rocky Mountains with what has been done in the central (Cooper 1975, Hoffman and Alexander 1976, Pfister 1972, Reed 1976, Wirsing and Alexander 1975), and northern Rocky Mountains (Daubenmire and Daubenmire 1968, Pfister et al. 1977, Steele et al. 1975), as well as elsewhere (Hall 1973, Sawyer and Thornburgh 1971, Westveld 1951) by the Forest Service.

\section{The Classification Framework}

The vegetation classification system proposed in this work represents what may be considered a physiognomic-ecological approach. The major units (formation, subformation) are physiognomic. Poore (1962) pointed out that for the major levels, ". . . physiognomy . . . reflects rather faithfully the sum total of the ecological factors of the habitat." The more fundamental units (series, as-

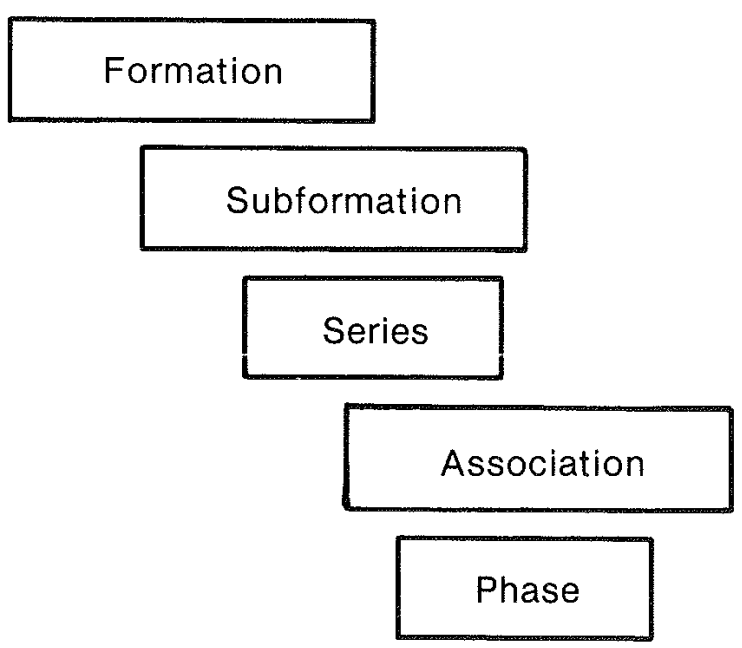

Figure 2.-The classification hierarchy-a taxonomic framework.

sociation, phase) are based on dominance and floristics. Whittaker (1962) referred to this approach as an "informal hierarchy" (fig. 2).

\section{Synecological Perspective and Terminology}

"Formations" are distinguished on the basis of a potentially uniform physiognomy at climax which represents a response from integration of the environmental factors. Formations are the broadest interpretive units of continental synecology. They include not only the climatic climax vegetation, which is the key to recognition, but all the various seral development stages as well. The term formation is Clementsian in origin, and was initially used without definition of rank (Pound and Clements 1898). Nothing here, however, is intended to imply adoption of the monoclimax ideas of Clements (1936).

The taxonomic levels (subformation, series, association) are categories that may be grouped into successively higher units. Thus, formations are groups of subformations and series with similar physiognomies.

"Subformations" refer to a distinctive physiognomy within a formation (Daubenmire 1968). For purposes of this paper, forest and woodland subformations are shown in figure 3 . The "biotic communities" mapped by Brown and Lowe (1977) approximate the formations and subformations described here.

"Series" encompass all the associations having the same potential dominant species at climax. Series are named after the climax dominant(s). The series name implies a particular potential vegetation and a predictable sere, although frequency of species in the succession may vary, depending on the kind and intensity of perturbation. For conifer- 


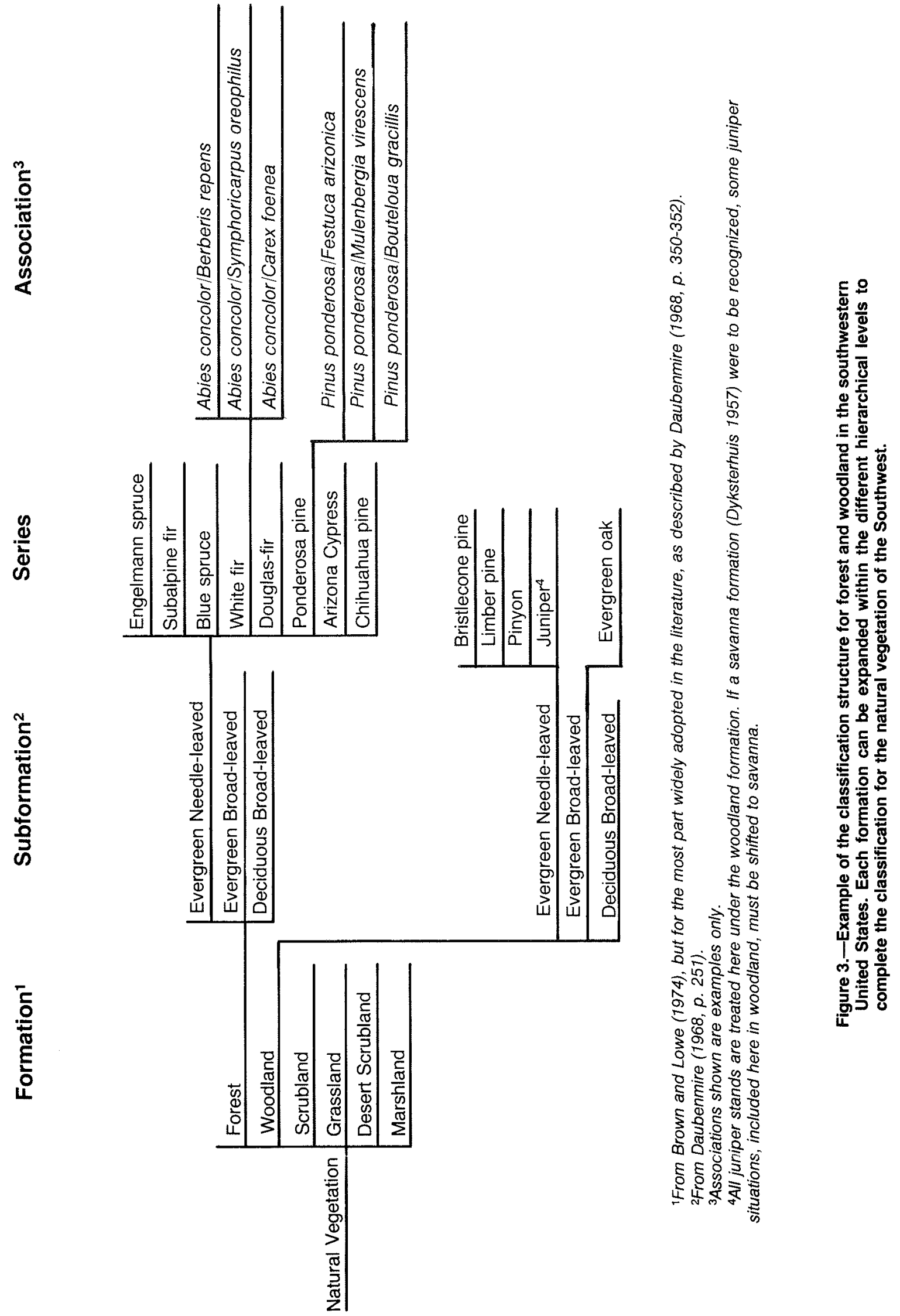


ous forest vegetation, the series are named after the climax tree species (Pfister et al. 1977, and Steele et al. 1975). Potential climax tree species are recognized on the basis of tolerance (ability to withstand shading) and their ability to reproduce despite a layer of duff and litter covering mineral soil (Graham 1941).

"Association" is a combination of overstory and understory climax dominants having similar or overlapping ecological requirements. A problem of inconsistency in use of this term was already apparent, when the International Botanical Congress of 1910 sought to standardize the definition of the term "plant association" to mean ". . . a plant community of certain floristic composition, of uniform habitat conditions, and of uniform physiognomy. Floristic composition includes not only the list of species, but also a (phyto) sociological evaluation based on abundance, dominance . . . constancy, fidelity . . ."

Collectively, those physical environments capable of supporting a particular climax plant association are called "habitat types" (Daubenmire and Daubenmire 1968). Theoretically, a habitat type displays uniformity of dominant vegetation in all layers at climax. For a more detailed discussion of the definition of habitat type and other synecological terms see Daubenmire (1976) and Pfister (1976).

"Phase" is a taxonomic term to designate subdivisions within an association and its habitat type. "Community type" (Hall 1973, Pfister et al. 1977) is a term applied to a recognizable and recurring stable plant community of uncertain successional status. In classification it is at the same hierarchical level as an association (figs. 2 and 3).

The use of the term "climax" in this paper follows the polyclimax concepts of Tansley (1935). The reference to climax vegetation in the development of the classification, and in nomenclature, in no way implies that climax vegetation is or must be a management objective. Neither does a climax stand need be present to identify a habitat type. The purpose in relating to climax in the development of the classification is to hold the time or successional factor constant (Pfister 1976), and to best ascertain the useful indicator plants (Daubenmire 1976).

Confusion has sometimes resulted between application of vegetative classification concepts and forest cover typing. Part of this may result from the fact that the term "forest type" was used by foresters in practically the same sense that association is now used by ecologists, long before the latter term originated (Clements 1920). However, a similar phrase, "forest cover type" (Society of American Foresters 1954), does not convey any implication as to whether the type is temporary or permanent. Therefore, even though the names used for a par-

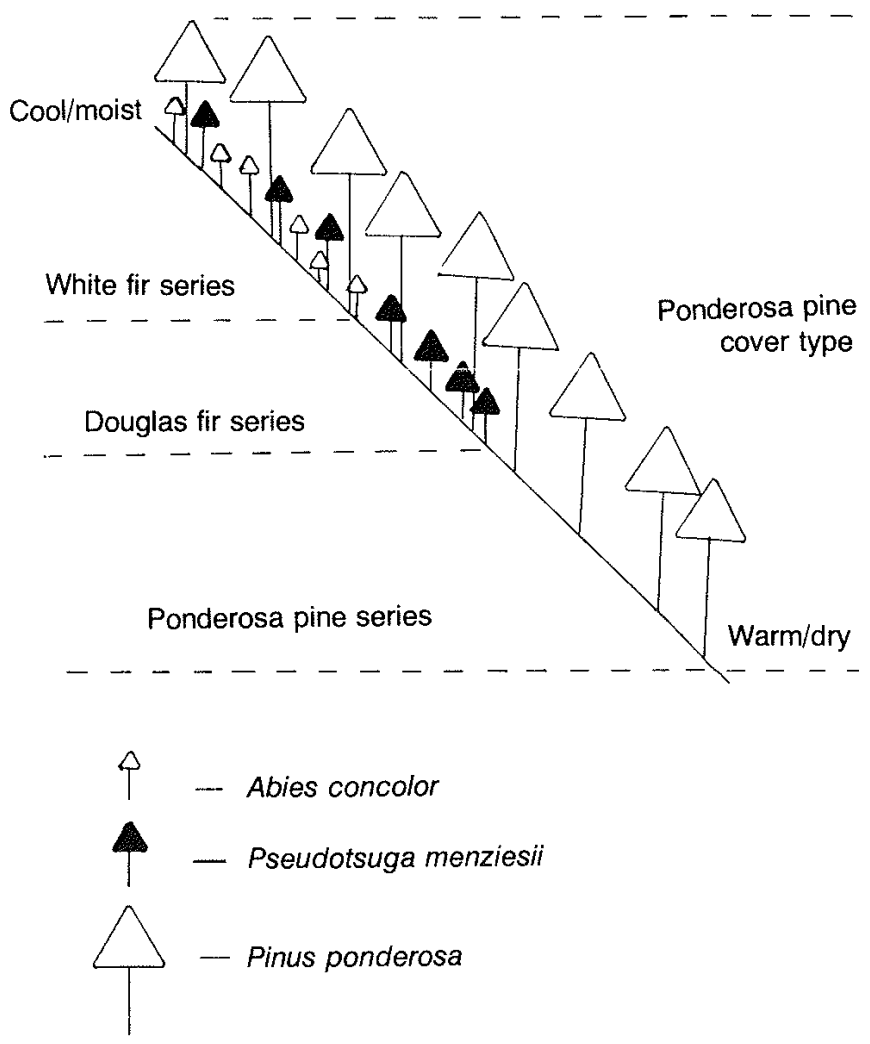

Figure 4.-Example of how a theoretical forest along an environmental gradient would be classified as to series and cover type. The site along the gradient that is occupied by ponderosa pine, which is too warm and dry for Douglas-fir and true firs, is the ponderosa pine series. Progressing toward cooler and moister situations, the Douglas-fir and white fir series are encountered, although all support a ponderosa pine cover type in the example.

ticular forest cover type and series maybe the same, there are fundamental differences between their meanings and applications (fig. 4).

Cover typing stresses uniformity of species composition to characterize existing stands (figs. $5,6,7$, and 8 ). There is no consideration of successional status. For example, a mature stand of ponderosa pine with a dense understory of Douglas-fir and Abies concolor would be cover typed ponderosa pine. Classified as to series, it would be $A$. concolor. The cover type tells something about the current forest cover, but, since ponderosa pine can range from the upper limits of the pinyon zone into the subalpine, it tells little if anything about the site. The series, by stressing the potential climax tree species, does not necessarily tell what forest cover currently exists, but it does communicate something about secondary succession, potential cover, and the site or environment. Both the cover type and potential vegetation are necessary information for management.

In the example above, the series is identified as white fir (Abies concolor); it is, therefore, im- 


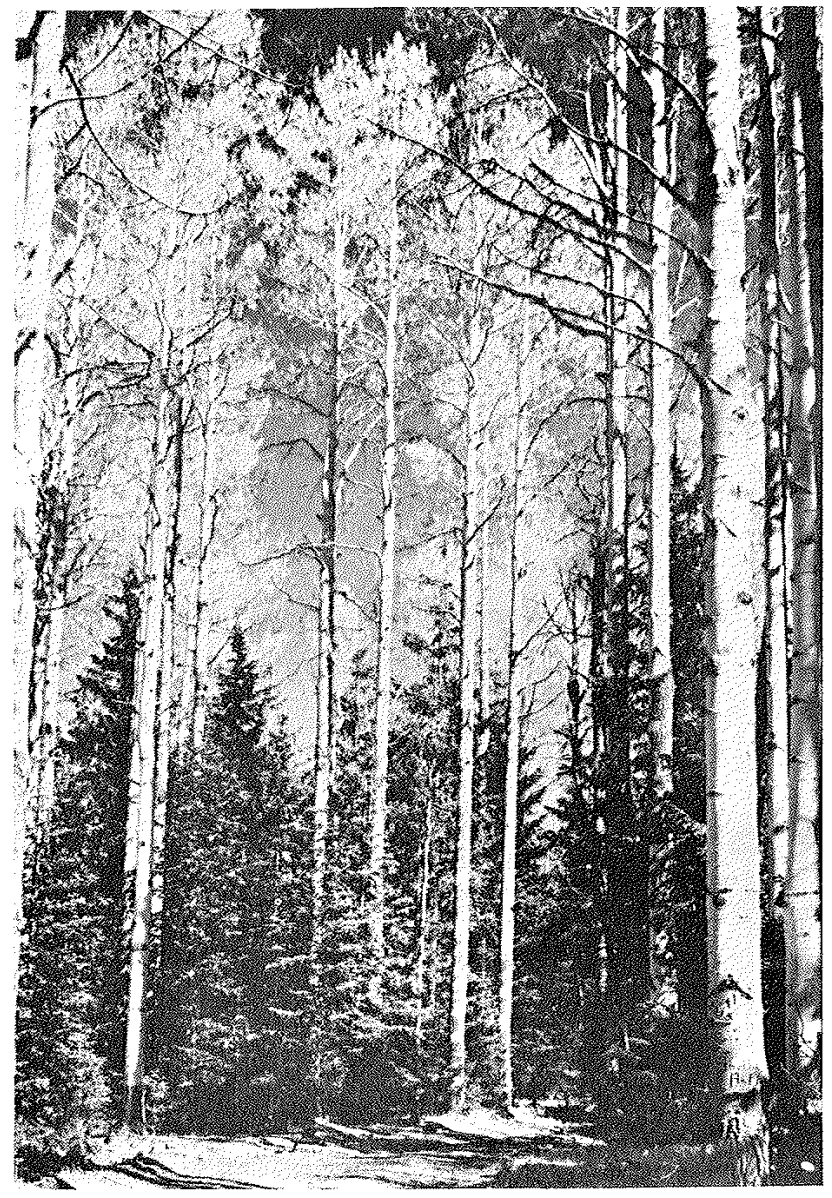

Figure 5.-Aspen is a common seral species in the spruce and true fir series in the Southwest. Over time, the aspen will give way to a succession of more tolerant conifer species. Here, an uncierstory of Douglas-fir and white fir is gradually replacing the aspen. Coconino National Forest Arizona.

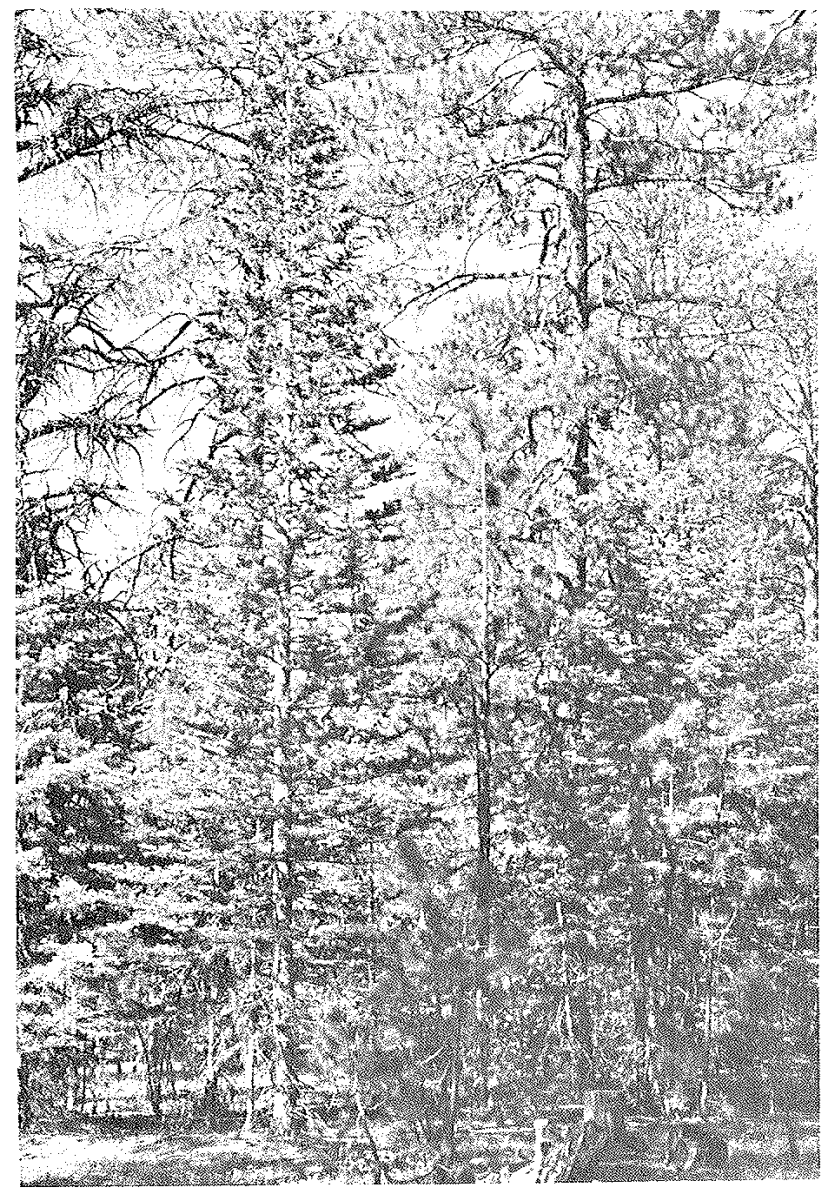

Figure 7.-Secondary succession where ponderosa pine is being replaced by a dense stand of white fir in Jemez Canyon, Santa Fe National Forest, New Mexico.
Figure 6. - Secondary succession in the white fir series. The site in the foreground is presently occupied by a dense stand of Quercus gambelii, under which a nearly pure stand of Abies concolor is developing. Sandia Mountains, New Mexico.

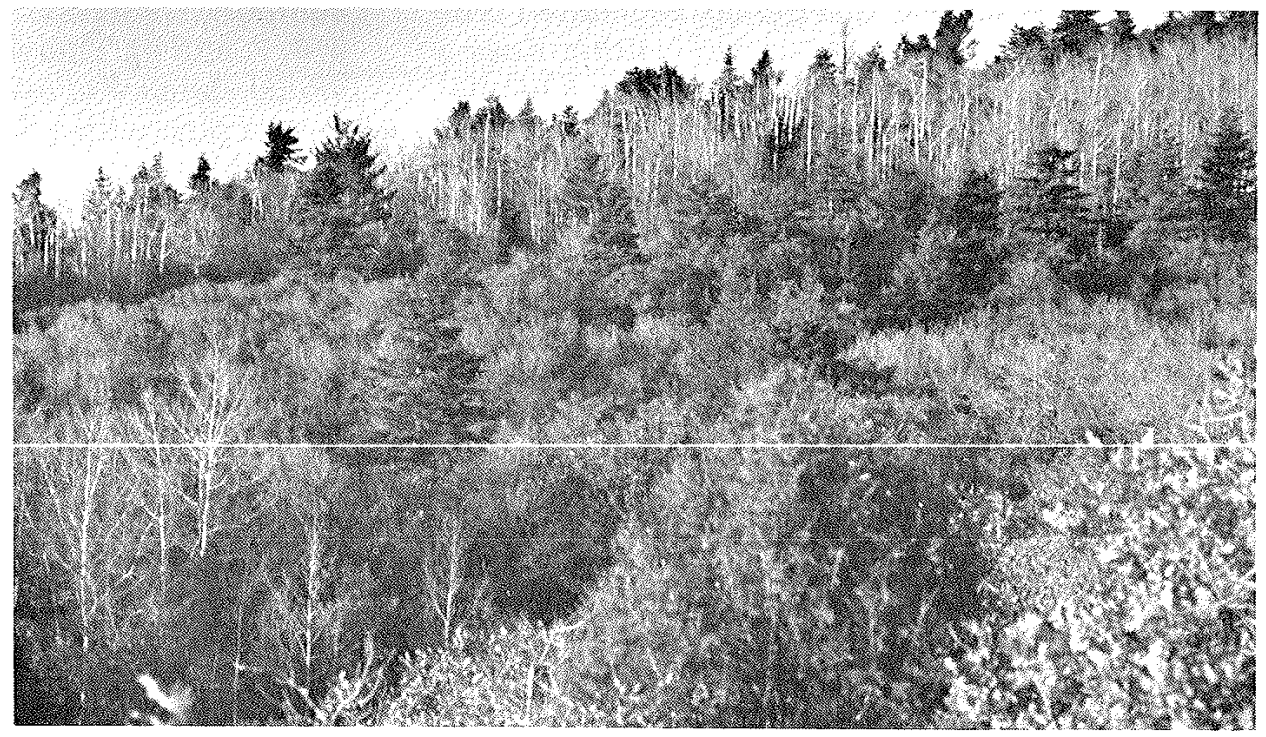


mediately known that the ponderosa pine stand is seral or temporary, and, assuming that no major disturbances such as fire intervene, the ponderosa pine will not maintain itself over time, but give way to a succession of more tolerant species. Also, the white fir series represents a cool-moist site relative to true ponderosa pine, and it can support a mixture of species, as compared to the latter, which is too warm and dry for Douglas-fir or true firs.

Confusion also has resulted from mixing geographic and vegetation taxonomic categories in certain recent attempts to develop hierarchical systems for land classification and mapping. A recent paper by Bailey et al. (1978), and discussion by Daubenmire (1968), and Kuchler (1973), helped to clarify this situation as follows:

\section{Taxonomic Terms}

Classification Levels
in the Taxonomic
Hierarchy

Formation

Subformation

Series

Association (community type) Phase

For example, zones are determined by the climax dominant species that are recognized as representing one segment of a sequence along a major environment gradient. In the Southwest, this is illustrated by the progression of tree species along an elevation gradient from ponderosa pine at moderate elevations to subalpine fir at higher eleva- tions. Therefore, it becomes feasible to construct two parallel keys, one of potential vegetation and one of habitat, which coincide (Pfister 1976, Poore 1962).

The principles of "competitive exclusion" and "monospecific dominance" (Daubenmire and Daubenmire 1968)-wherein several trees may find the physical conditions of a site within their range of ecologic amplitudes, but only one of them will eventually dominate over time because of competitive superiority-sometimes are not apparent in the forests of the Southwest, especially in arid or subtropical situations. Two or more species may appear equally adapted and competitive within the same habitat. Therefore, forest or woodland series, in some cases, may involve coor multi-dominance, but still be named after a single tree species (table 1). Naming series after a single climax dominant species or associations by binomials, does not imply monospecific dominance.

Habitat types and zones are generally named after the associations and series they respectively support. For example, the ponderosa pine series represents the ponderosa pine zone, and the Pinus ponderosa/Festuca arizonica association identifies the $P$. ponderosa/F. arizonica habitat type.

The potential vegetation concept can convey more information for management about the site than cover typing (Volland 1975). Because vegetation effectively reflects the integration of environmental factors, it may be used in a relative sense to assist in the identification of areas of "equivalent biotic potential" (Rowe 1960, Lowe 1964). This is important to mapping, because, whereas the cover type is temporary, a map of the potential natural vegetation is as permanent as the land itself (Daubenmire 1973, 1976).

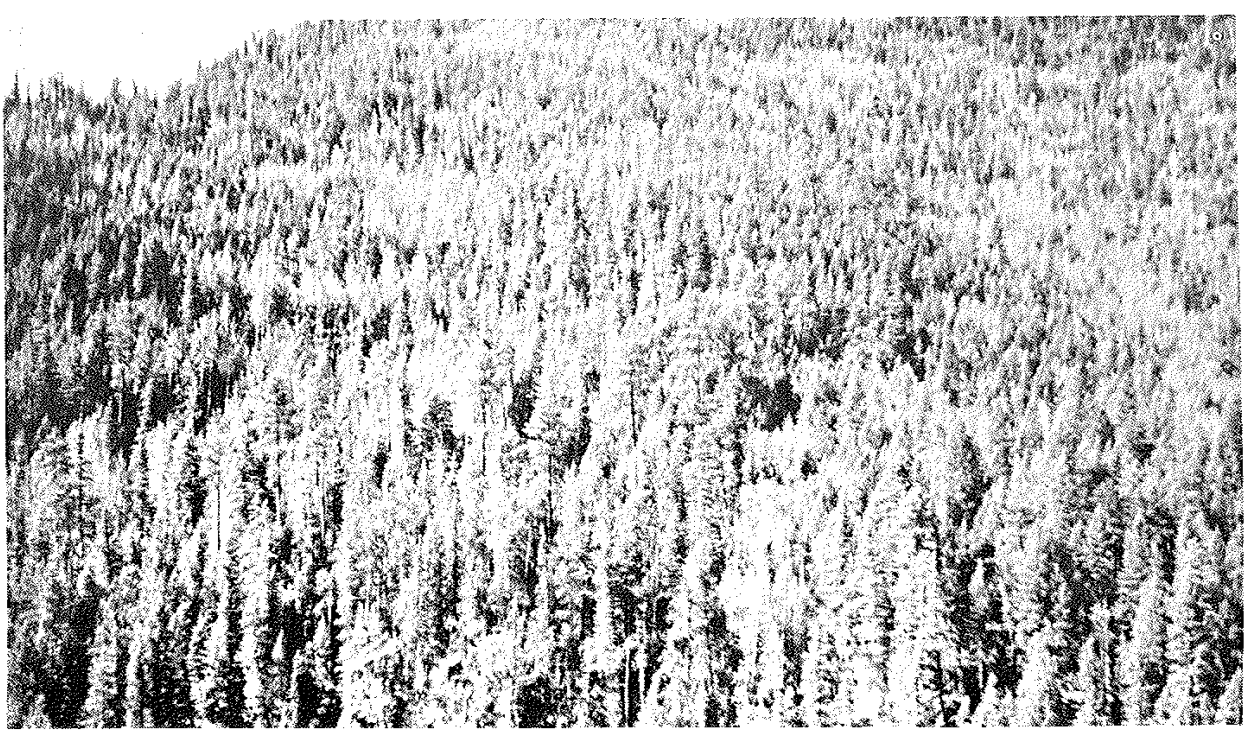

Figure 8. - Densely forested places at relatively moderate eleyations often support stands of mixed species composition. Generally, these stands are Abies con. color series. Carson Nation. al Forest, New Mexico. 
Table 1. Estimated distribution and successional role of tree species in forest and woodland series of the Southwest

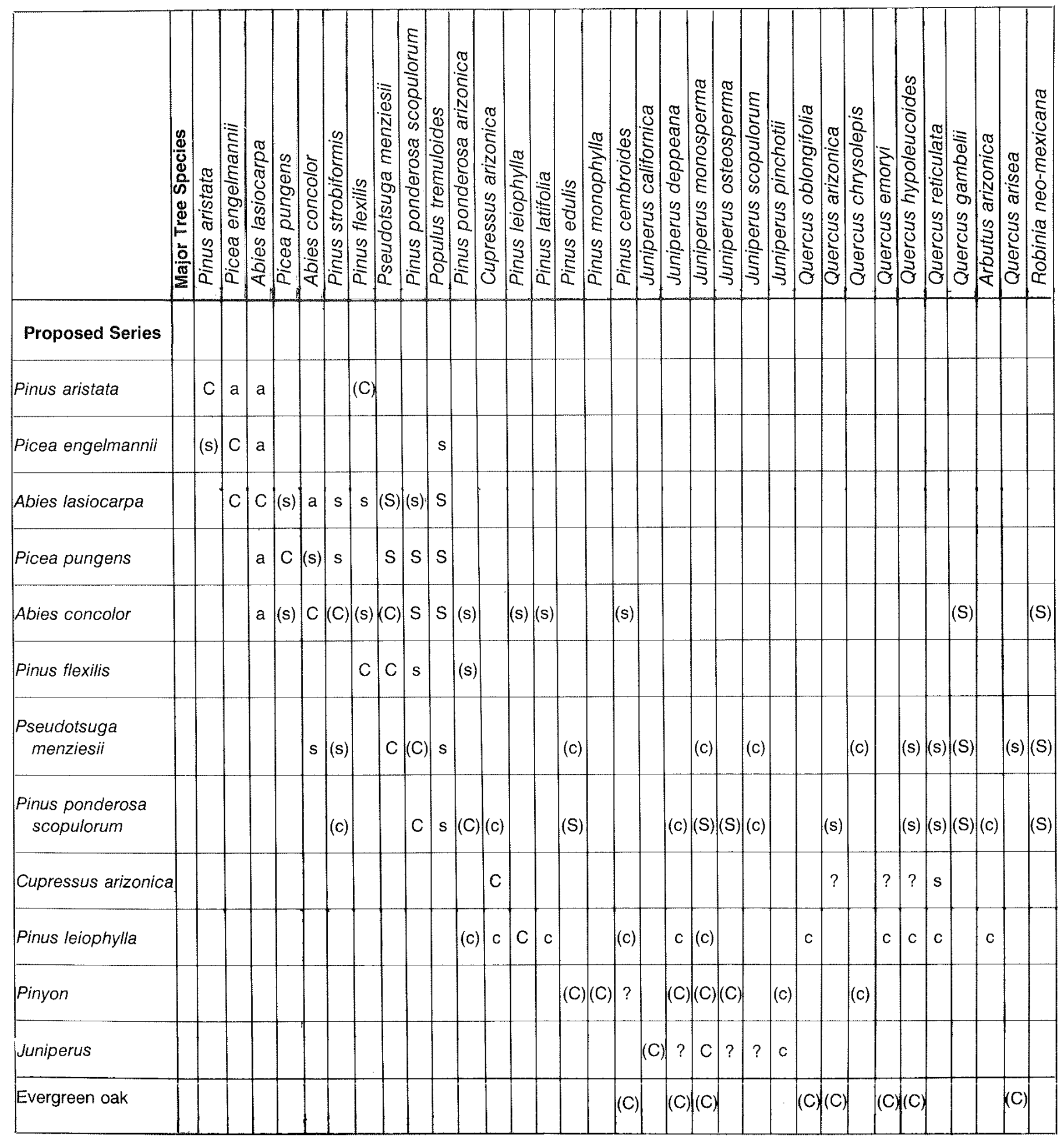

+ Legend: $C=$ dominant; $c=$ minor climax species; $a=$ accidental; $S=$ major seral species, usually long lived; $s=$ minor seral species; ()=in some places, but not everywhere in the Southwest 


\section{PRELIMINARY CLASSIFICATION OF CONIFEROUS FOREST AND WOODLAND SERIES}

\section{Methods}

A preliminary classification for the coniferous forest and woodland series, within the vegetation classification framework described earlier, is proposed here for the Southwest. The proposed classification is based upon the literature, field observations, and data of Moir and Ludwig (1977), and Hanks et al. (1977), following procedures developed by Daubenmire and Daubenmire (1968), and Pfister and Arno. ${ }^{6}$ This work is a first step in the development of a vegetation classification by a method of "successive approximations" (Poore 1962). As new knowledge is obtained, the classification can be extended and improved.

6Pfister, Robert D., and Stephen F. Arno. (In press). Classifying forest habitat types based on potential climax vegetation. Manuscript submitted to Forest Science on December 5, 1978.

\section{Results}

Eight coniferous forest and five woodland series are proposed. Table 1 lists the series, and shows the estimated distribution and successional status of trees species within the series classification. Figure 9 shows the distribution of the major tree species encountered with increasing elevation.

A dichotomous key for the classification is followed by general descriptions of the series. The key leads imply potential to support the climax dominants. Generally, "present and successfully reproducing" refers to the presence of 10 or more individuals of the species per acre that are obviously not just confined to microsites; accidentals are considered to be fewer than 10 trees per acre (Pfister et al. 1977, Steele et al. 1975). The use of fewer than 10 trees per acre as criteria for accidentals is somewhat arbitrary and may have less va. lidity in semiarid, open forest or woodland types. This needs to be further evaluated in field studies. Criteria for accidentals may then be adjusted as appropriate.

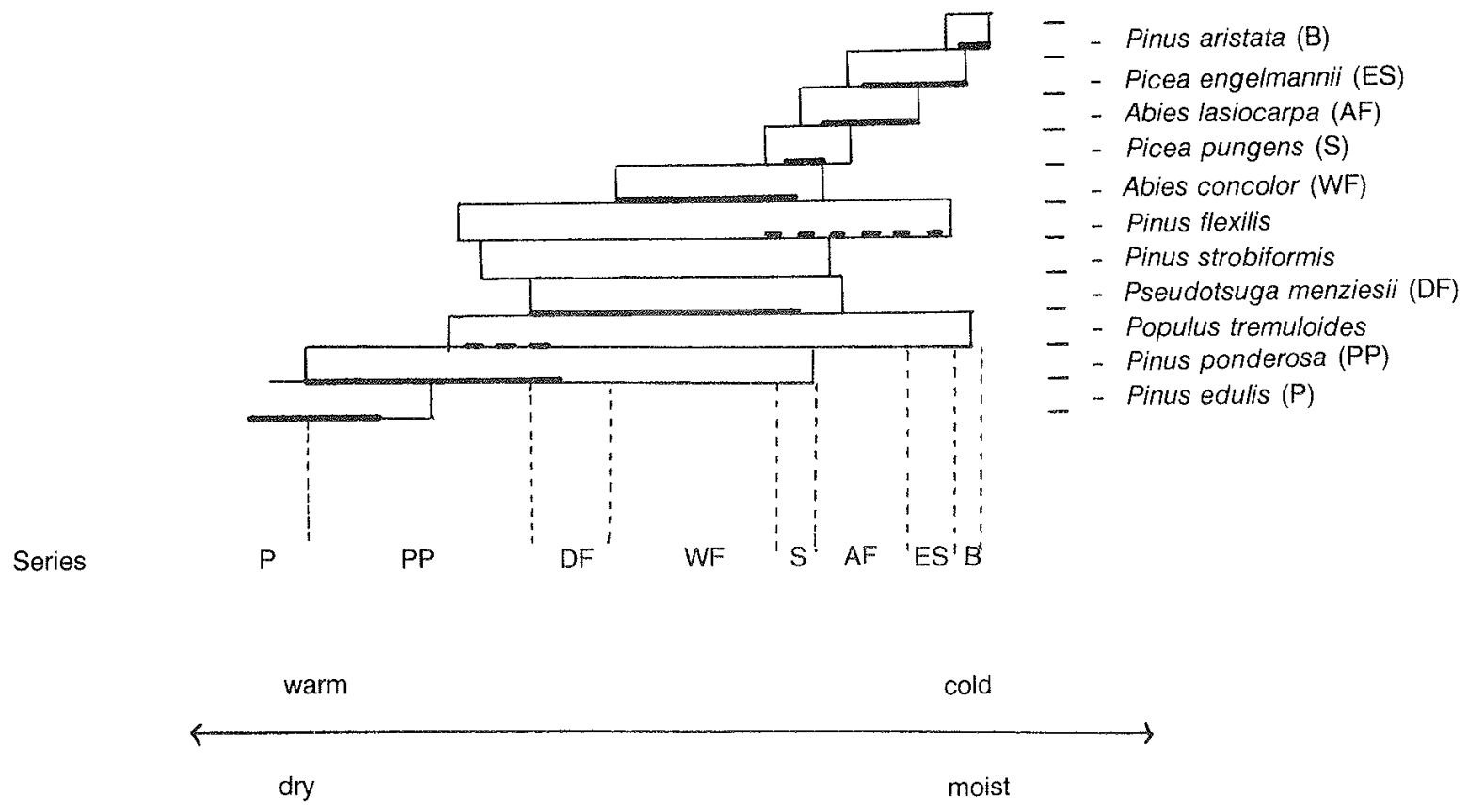

Figure 9.-An estimation of the distribution of tree species encountered with increasing elevation. The horizontal bars designate upper and lower limits of the species relative to the environmental gradient. The diagram treats only those series above the Pinyon Zone. The part of the tree species range in which it is estimated to occupy the role of a climax species is indicated by the heavy line. Habitats representing edaphic or topo-edaphic climaxes do not fit neatly into the scheme of depicting or generalized temperature-moisture gradient and are generally indicated by a heavy broken line. 


\section{Descriptive Key to the Coniferous Forest and Woodland Series}

1. Dominant vegetative strata comprised principally of trees potentially over 50 feet in height characterized by closed and/or multi-layered canopies . . . FOREST FORMATION . . . 2

1. Dominant strata comprised of trees, but with a mean potential height under 50 feet, the canopy of which is usually open, or very open, and singular . . . WOODLAND FORMATION . . . 10

2. Trees deciduous and broadleaved (often confined to canyon bottoms, drainageways, or floodplains), consisting of pure or mixed stands of $A \ln u s$, Fraxinus, Juglans, Platanus, and Populus ... DECIDUOUS FOREST SUBFORMATION

2. Trees evergreen and needle-leaved . . CONIFEROUS FOREST SUBFORMATION . . . 3

3. Abies lasiocarpa and/or Picea engelmannii present and successfully reproducing, and clearly not just confined to microsites . . . 4

3. Abies lasiocarpa and/or Picea engelmannii absent or accidental . . . 5

4. Abies lasiocarpa present and successfully reproducing; Picea engelmannii sometimes strongly codominant . . . ABIES LASIOCARPA SERIES.

4. Abies lasiocarpa absent or accidental; Picea engelmannii present and successfully reproducing, often occurring in relatively pure stands . . . PICEA ENGELMANNII SERIES.

5. Picea pungens present and successfully reproducing; Pseudotsuga sometimes codominant; often confined to lower slopes, moist bottoms, and meadow margins . . . PICEA PUNGENS SERIES

5. Picea pungens absent or accidental . . . 6

6. Abies concolor present and successfully reproducing, sometimes codominant with Pseudotsuga meriziesii or Pinus strobiformis; Pinus ponderosa often present as a long-lived seral species . . ABIES CONCOLOR SERIES

6. Abies concolor absent or accidental ... 7

7. Pseudotsuga menziesii present, sometimes codominant with Pinus ponderosa; Abies, Picea, or Pinus flexilis absent or accidental . . . PSEUDOTSUGA MENZIESII SERIES

7. Pseudotsuga absent or confined to microsites .. 8
8. Pinus leiophylla and/or P. latifolia present, generally codominant with Cupressus arizonica, Juniperus spp., Pinus cembroides and/or evergreen oaks; Pinus ponderosa, if present, represented by the var. arizonica . . . PINUS LEIOPHYLLA SERIES

8. Pinus leiophylla and/or P. latifolia absent or accidental; dominant vegetation not as described above . . . 9

9. Pinus ponderosa present and successfully reproducing, often occurring in pure stands, but may also be codominant with pinyon, juniper, and/or evergreen oaks in some areas; Pinus ponderosa generally represented by var. scopulorum, but in some places in southern Arizona by var. arizonica . . . PINUS PONDEROSA SERIES

9. Cupressus arizonica the dominant tree species, forming nearly pure stands; generally local in occurrence and confined to northfacing slopes of canyon bottoms . . . CU. PRESSUS ARIZONICA SERIES

10. Woodlands dominated by broad-leaved deciduous species such as Acer, Alnus, Morus, Prosopis, Prunus, and Salix, often confined to waterways ... DECIDUOUS WOODLAND SUBFORMATION

10. Woodlands of other than deciduous broadleaved species . . . 11

11. Woodlands dominated by evergreen broadleaved species (in our area primarily oaks such as Q. emoryi, Q. hypoleucoides, Q. arizonica) . . . EVERGREEN OAK SERIES

11. Woodlands dominated by evergreen needleleaved species ... CONIFEROUS WOODLANDS SUBFORMATION . . . 12

12. Pinus aristata present, often in relatively pure (and ancient) stands at high elevations; sometimes codominant with Pinus flexilis and/or Picea engelmannii . . . PINUS ARISTATA SERIES

12. Pinus aristata absent or accidental . . . 13

13. Pinus flexilis present, sometimes codominant with Pseudotsuga menziesii, mostly confined to lithosolic situations in the mountains at relatively high elevations . . PINUS FLEXIIS SERIES

13. Pinus flexilis absent or accidental . . . 14

14. Pinyon (Pinus cembroides, $P$. edulis, or $P$. monophylla) present and not just confined to microsites; often codominant with Juniperus spp. . . . PINYON SERIES 
14. Pinyon absent or widely scattered in microsites; Juniper (Juniperus deppeana, J. monosperma, J. osteosperma) present forming open to very open (savanna), pure or mixed stands . . . JUNIPERUS SERIES

\section{Discussion}

Forest vegetation may begin about 5,000 feet and occur up to timberline, about 11,500 feet, in the Southwest. Patterns of forest vegetation are generally stratified altitudinally (Merriam 1898). Forest species are commonly depicted in a series of altitudinal belts (Spencer 1966). This phenomena has been the focus of considerable plant ecology research in the Southwest (Shreve 1922, Whittaker and Niering 1975).

Upon close inspection, however, altitudinal belts of forest vegetation exist only in a general sense (Watson 1912, Shreve 1922, Whittaker and Niering 1975). For example, Daubenmire (1943) described vegetation distribution patterns by stating that, "Zones in the sense of rigidly defined altitudinal belts clearly do not exist . . . but no careful student of plant sociology . . . would deny the existence of regularly repeated series of distinct vegetative types, each of which bears a constant altitudinal or topographic relationship to contiguous types."

Essentially, altitude is only one factor in determining occurrence of plant communities. Others, such as slope, aspect, cold air drainage, precipitation patterns, and soil characteristics, interact to create a mosaic of habitat types in mountainous terrain (fig. 1). Understanding the natural distribution of tree species and their role in forest succession in relation to these different types of habitats is fundamental to forest land management (Daubenmire 1976, Pfister 1972).

The following relates the literature and describes the general basis for recognition of the different series.

\section{General Series Descriptions}

Pinus aristata series.-The Pinus aristata series occurs at high elevations. It appears to occupy cold, dry sites. It may occur in pure ancient stands or with Pinus flexilis. At its lower elevational limits, it grades into the Picea engelmannii or the Abies lasiocarpa series. In some cases, it may border the Pinus flexilis series. Picea engelmannii, which occupies cold, wet sites, may go above Pinus aristata in elevation at places. The P. aristata series is widely scattered and minor in occurrence. It is known from the highest mountains of the Sangre de Cristo Range and the San Francisco Peaks (Schubert and Rietveld 1970) (fig. 10), and from high peaks in Colorado, Utah, Nevada, and California (Little 1950). The series ${ }^{7}$ is recognizable in work by Brown and Lowe (1974), Kuchler

${ }^{7}$ Not all authors cited used the series category. Different authors may classify similar types at different taxonomic levels. The important point is that the type was recognized by others as a recurring entity warranting taxonomic treatment.

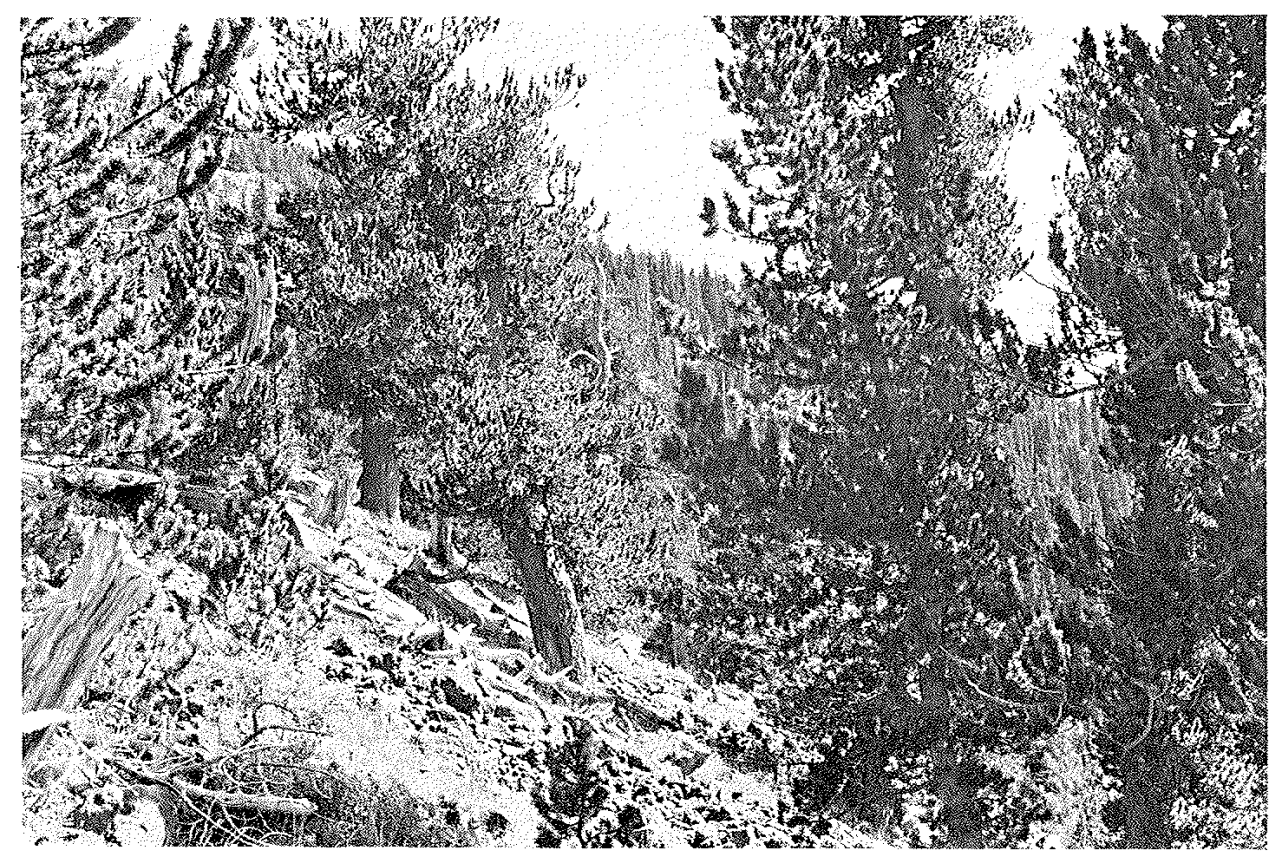

Figure 10. - Pinus aristata series, San Francisco Peaks, Coconino National Forest, Arizona. 
(1964), Lowe (1964), Pearson $(1920,1931)$, and the Society of American Foresters (1954).

Picea engelmannii series.-Engelmann spruce is reported to go above Abies lasiocarpa in altitude in the Southwest. At places it occurs with virtual exclusion of any other trees (Pearson 1931, Pfister 1972). Those habitats where Engelmann spruce forms nearly pure stands, with Abies lasiocarpa being absent or accidental, are recognized as the Picea engelmannii series (fig. 11). The series grades into Pinus aristata series at high elevations, and Pinus flexilis on steep, south-facing slopes and exposed ridges. At lower elevations, it forms ecotones with the Abies lasiocarpa or Abies concolor series. The Picea engelmannii series is recognizable in work by Moir and Ludwig (1977), Pearson (1931), Pfister (1972), and Brown and Lowe (1974).

Abies lasiocarpa series.-The Abies lasiocarpa series is typified by stands of Picea engelmannii with variable amounts of Abies lasiocarpa in association (figs. 12 and 13). The key factor for recognizing the series is that Abies lasiocarpa is present and successfully reproducing. Aspen is a notable seral species, and Pinus contorta is conspicuously absent from the series in the Southwest (Kuchler 1964). In the Southwest, there is little evidence that succession in spruce-fir stands tends toward dominance by Abies lasiocarpa (Jones 1974). Therefore, the Abies lasiocarpa series, as proposed, generally represents a situation of codominance between Picea engelmannii and Abies lasiocarpa. Stands dominated by $A$. lasiocarpa would also belong to this series. Spruce

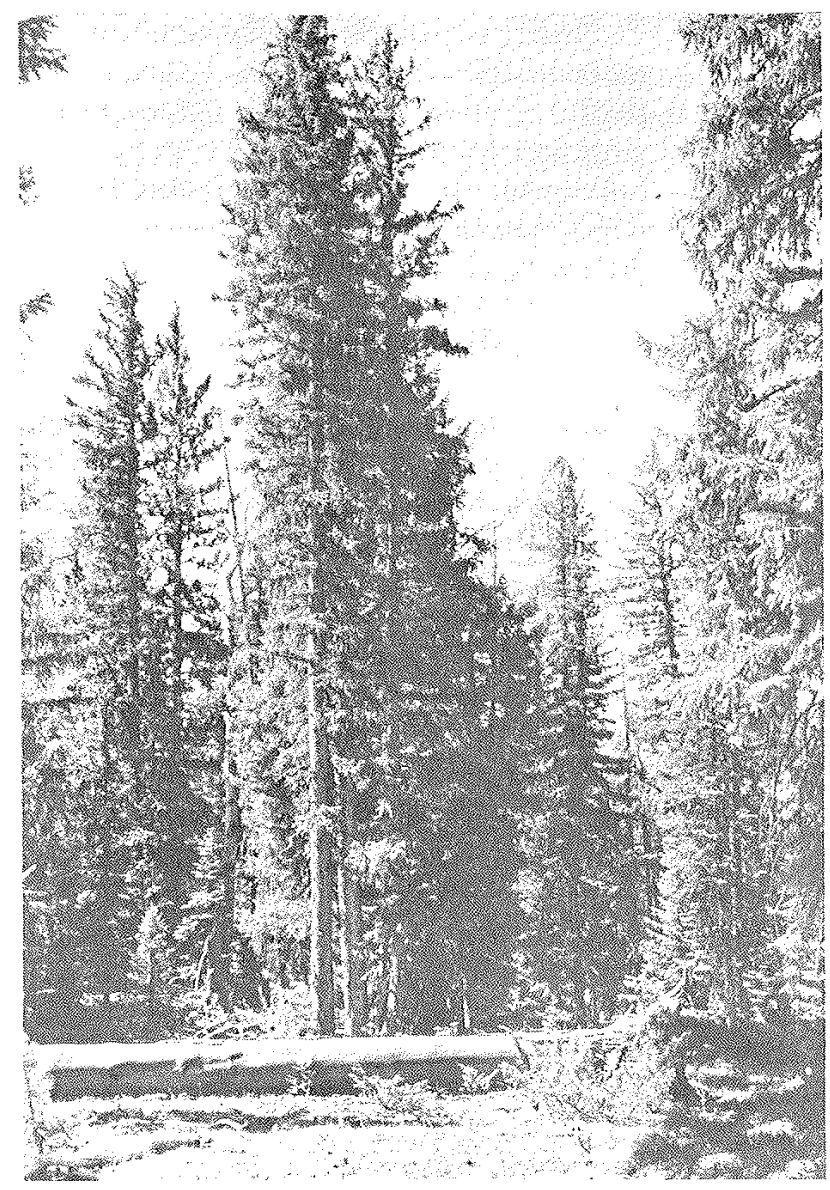

Figure 12.-Abies lasiocarpa series, Kaibab National Forest, Arizona.

Figure 11.-Picea engelmannii series, Truchas Peaks area, Santa $\mathrm{Fe}$ National Forest, New Mexico.

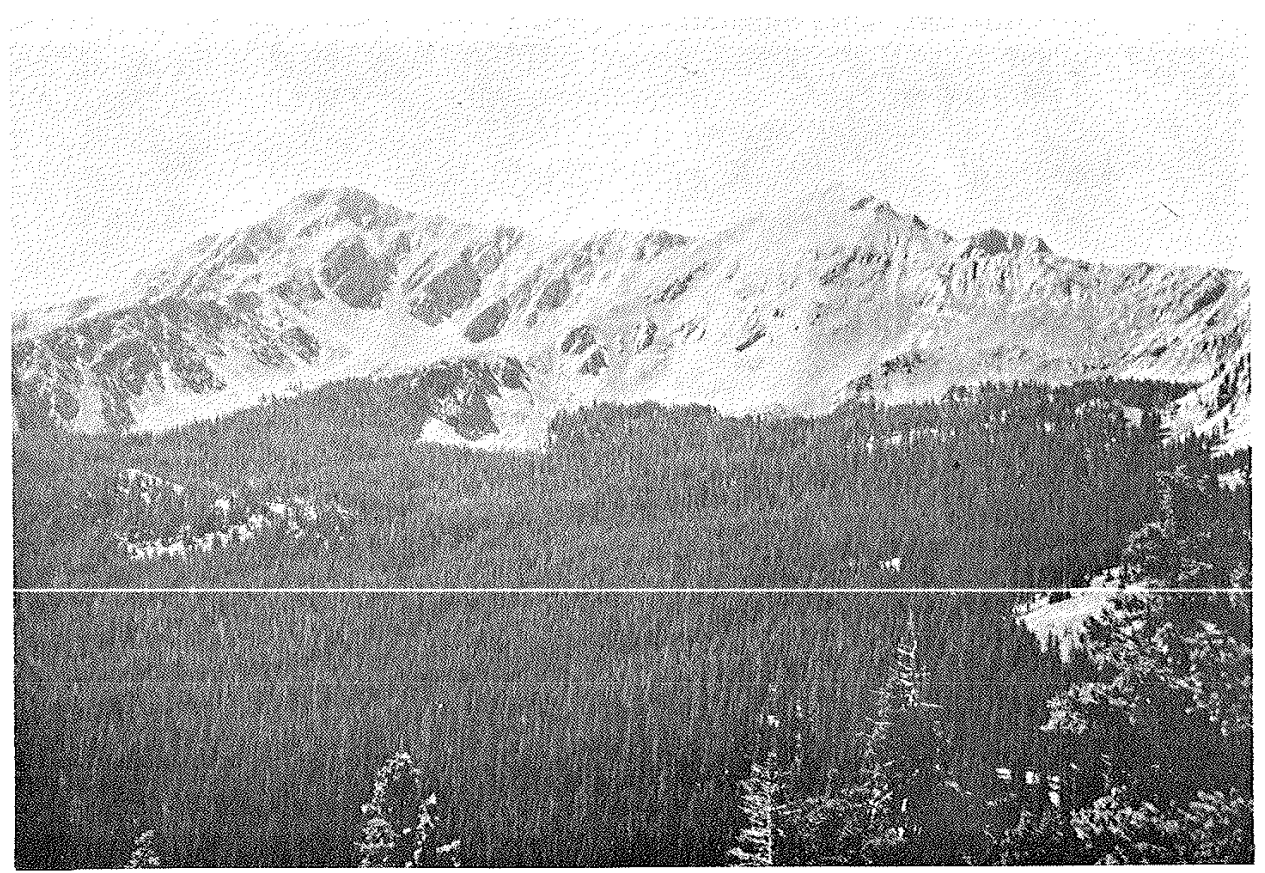


bark beetle outbreak or removal of spruce tends to favor fir reproduction (Alexander 1973), but apparently not to the exclusion of spruce. Understanding of the successional relationships in this series may be complicated by the fact that, in the Southwest, two varieties of the fir occur-A. lasiocarpa var. lasiocarpa (subalpine fir) and A. lasiocarpa var. arizonica (corkbark fir). On the Kaibab Plateau and other places, subalpine fir replaces corkbark fir (Lowe 1964). Whether the varieties reflect environmental differences, or assume different roles in succession, is not known. Because of lack of any basis at this time to do otherwise, corkbark and subalpine fir have both been included in the proposed Abies lasiocarpa series. The series, as proposed, includes the Engelmann spruce-subalpine fir type referred to by many authors, but distinguishes between those habitats where subalpine or corkbark fir does not occur. At upper limits, the series forms ecotones with the Pinus flexilis or Picea engelmannii series, and, at its lower limits, it grades into the Abies concolor or Picea pungens series. The Abies lasiocarpa series is recognizable in work by Brown and Lowe (1974), Kuchler (1964), Lowe (1964), Merkle (1954), Moir and Ludwig (1977), Pearson (1920, 1931), Pfister (1972), Society of American Foresters (1954), and Whittaker and Niering (1975).

Abies concolor series.-The Abies concolor series is characterized by the presence and successful reproduction of $A$. concolor (figs. 6, 8, and 14). Subalpine fir and Engelmann spruce are sometimes present as accidentals. Pseudotsuga menziesii, and at places Pinus strobiformis, appear codominant (fig. 15). Pinus ponderosa is a long-

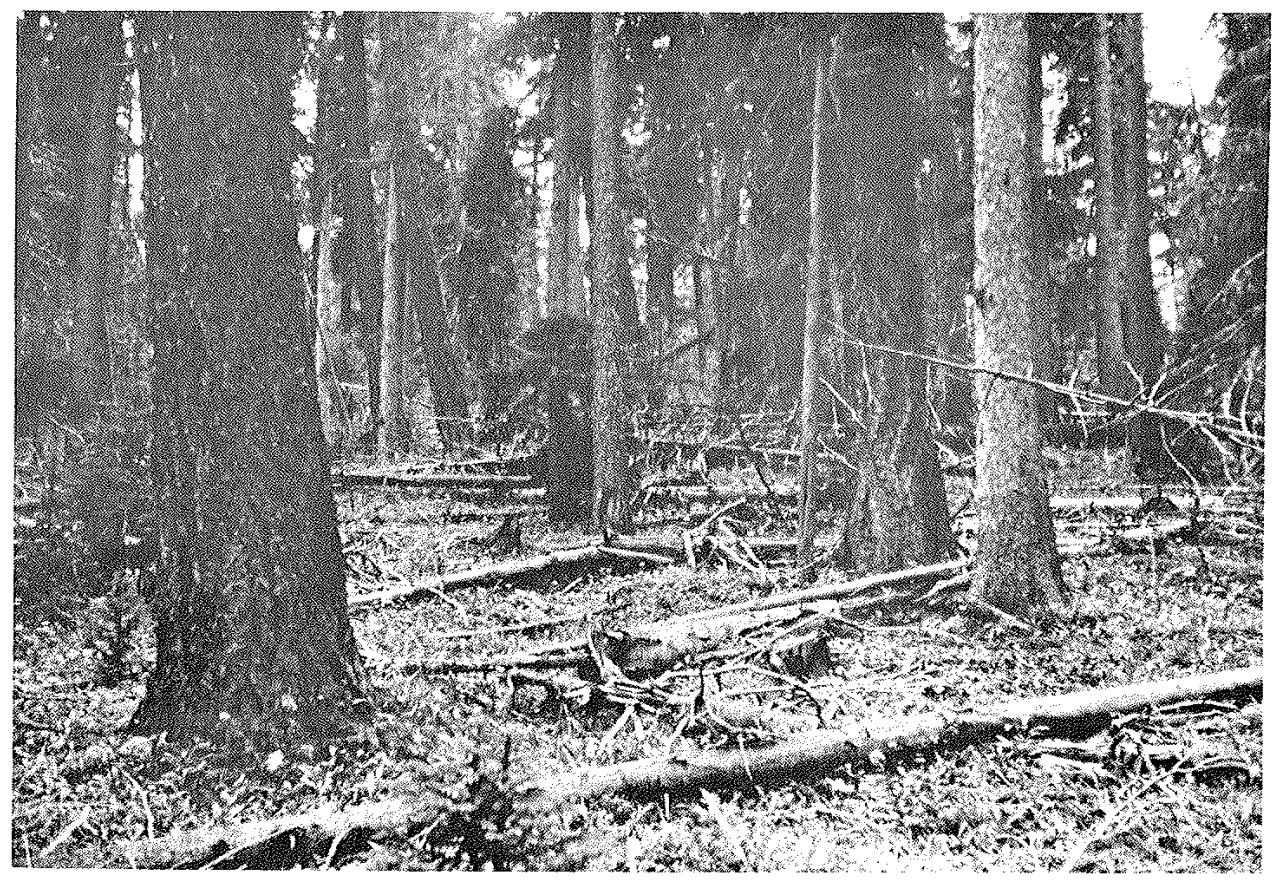

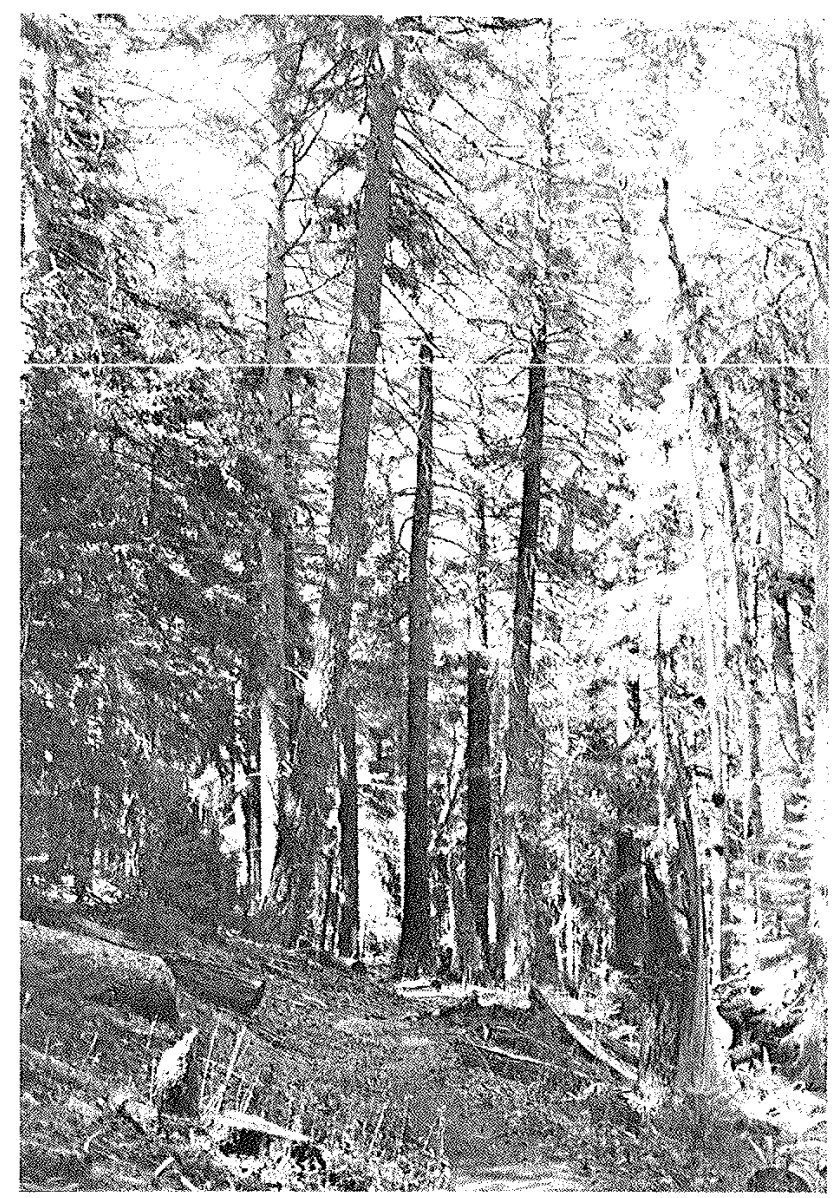

Figure 14.-Abies concolor series, Santa Fe National Forest, New Mexico.

Figure 13. - Abies lasiocarpa series, Santa Fe National Forest, New Mexico. Engelmann spruce is codominant, and Douglas-fir is a long-lived seral species. 


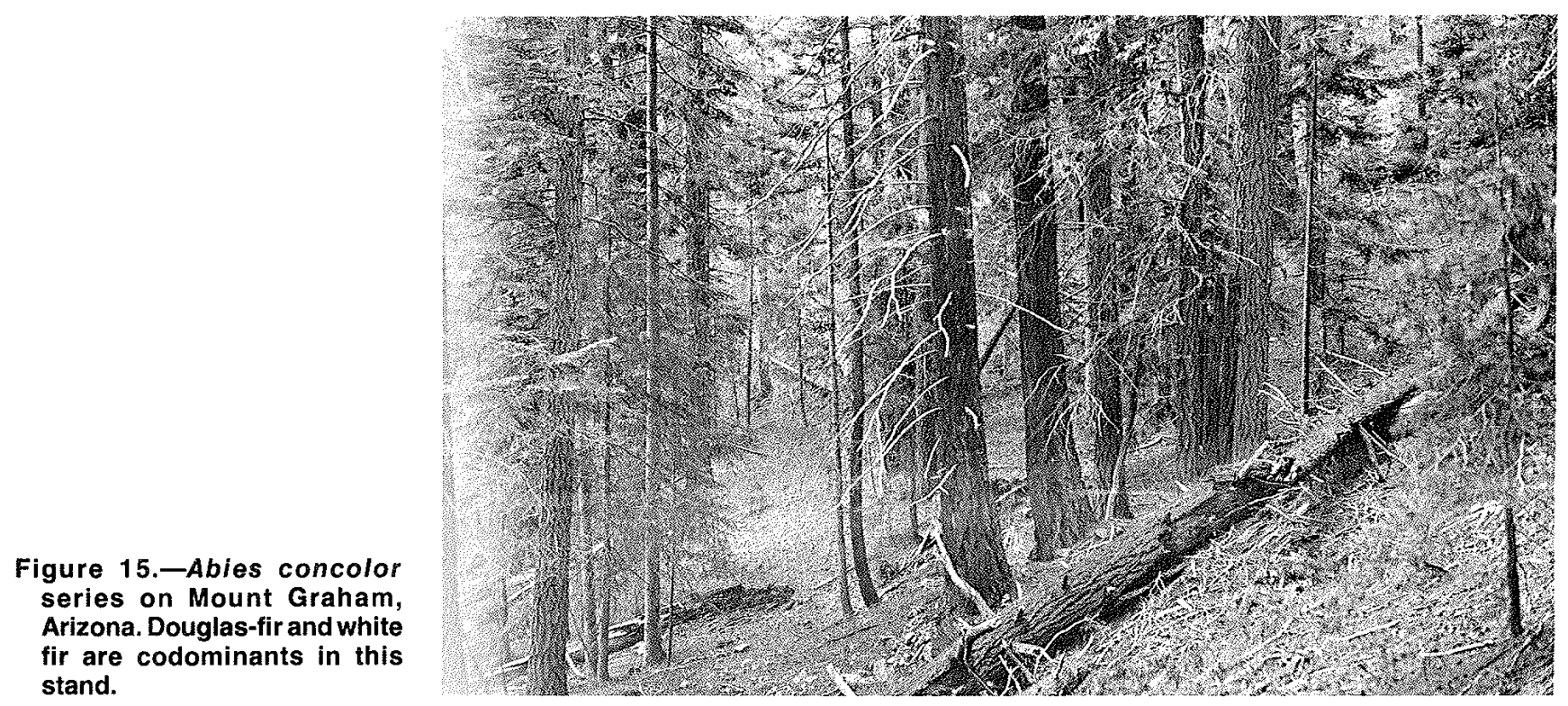

lived seral species. Habitats representing the Abies concolor series sometimes support fire-maintained stands of Pinus ponderosa and Pseudotsuga menziesii, but those situations can generally be recognized by occurrence of Abies concolor in the understory. Aspen is a notable seral species in this series. The $A$. concolor series and its ecotones with the Abies lasiocarpa series, have often been referred to as "mixed conifer forest."

Nearly pure stands of Abies concolor occur at places such as on the east slope of the Sandia Mountains, New Mexico, where Castetter (1956) remarked on the "extensive solid stands," or at places in the Black Range, New Mexico, and elsewhere. Photos of old growth stands of $A$. concolor and Pseudotsuga on the Santa Catalina Mountains, Arizona, are often figured in vegetation studies (Lowe 1964, Turner 1974).

The $A$. concolor series has the most complex ecotone relationship of any of the southwestern forest series. It may occur adjacent to nearly every other forest series, but most often it grades into the Douglas-fir or ponderosa pine series at lower elevations and the subalpine fir series at higher altitudes.

Successional relationships in this series, as in others, may be complicated by floristic differences in the various mountain ranges of the Southwest. Aspen, Gambel oak, and New Mexico locust are common seral species in some areas. In the mountains of southern Arizona, five-needled pines and evergreen oaks may replace species more commonly associated with $A$. concolor, as is the case in the Huachuca Mountains, Arizona, where $A$. concolor reportedly occupies the highest elevation zone (Wallmo 1955). In the Organ Mountains, New Mexico, it is reported as a topo-edaphic climax (Dick-Peddie and Moir 1970).
From reports in the literature, the $A$ bies concolor series appears to be represented in nearly all the major mountain ranges in the Southwest (Castetter 1956; Dick-Peddie and Moir 1970; Merkle 1954. 1962; Moir and Ludwig 1977; Pfister 1972; Wallmo 1955; and Whittaker and Niering 1975).

Picea pungens series.-The Picea pungens series represents a topo-edaphic climax bordering meadows, stream banks, and bottoms in the Southwest (fig. 16). It is typified by dominance of Picea pungens on those habitats that are too warm and dry for Picea engelmannii or Abies lasiocarpa. Douglas-fir and ponderosa pine may occur as long lived seral species.

The Picea pungens series may form ecotones with the Abies concolor, Abies lasiocarpa, Pseudotsuga series and deciduous riparian forest or woodland riparian types. Generally, where Picea pungens occurs in association with Abies concolor or $A$. lasiocarpa, it must be considered seral, since it is the least tolerant of the three species (Pfister 1972). Lowe (1964) reports, "blue spruce is a major dominant on the extensive summit area of the Kaibab Plateau, where it dominates the forest bordering mountain grasslands."

Moir and Ludwig have revised their 1977 manuscript to recognize low-elevation situations where Abies lasiocarpa, Picea engelmannii, and Picea pungens occur, as being the $P$. pungens series (Moir and Ludwig 1979). Their reasoning was that these stands occur at too low an elevation for $P$. engelmannii or $A$. lasiocarpa series. The authors' interpretation of this situation is that these are frost pocket sites in which the occurrence of subalpine and Engelmann spruce is depressed in elevation below where one would normally expect to find these species occurring as dominants. These sites will key to $P$. engelmannii or $A$. lasiocarpa series in the authors' key to series. 
Daubenmire and Daubenmire (1968) reported similar low elevation occurrence of $A$. lasiocarpa in frost pockets in the steppe of Washington. This phenomena is not inconsistent with the classification proposed here. Other examples where environmental factors compensate with one another to produce a community, which can at first appear incongruent to the vegetative zone, are not uncommon. These are sometimes called, "topoedaphic climaxes" or "habitats of compensation" (Daubenmire 1968). In any case, the point should be stressed that this paper and Moir and Ludwig's are preliminary, and additional research may be required to resolve questions of this kind that may be raised by either work.

The series may be complicated by taxonomic problems between $P$. pungens and $P$. engelmannii, similar to those described by Pfister et al. (1977) for $P$. engelmannii and P. glauca in Montana.

The Picea pungens series has been recognized as a category by Brown and Lowe (1974), Kuchler (1964), Moir and Ludwig (1977), Pfister (1972), and Society of American Foresters (1954).

Pinus flexilis series.-The Pinus flexilis series represents a topo-edaphic climax generally associated with lithosolic situations at high elevations, or occasionally extending to lower elevations on southern windswept exposures (fig. 17). Pinus flexilis may appear in pure stands, or Douglas-fir may sometimes be a codominant. Ponderosa pine sometimes shows up as a long lived seral species. The Pinus flexilis series as described here is separate from where the species occurs in association with Abies lasiocarpa, Picea engelmannii, or Pinus aristata. Those situations, where
P. flexilis is seral, are treated within the subalpine fir, Engelmann spruce, or bristlecone pine series.

The limber pine series is complicated by the taxonomy, and possible hybridization, between Pinus strobiformis and P. flexilis. The former has been treated as a variety ( $P$. flexilis var. reflexa) by some authors (Little 1950). Considerable confusion exists between these two trees in the Southwest. Generally, the limber pine series is represented by subalpine or lithosolic woodland situations; whereas, southwestern white pine is generally found in forest situations.

The limber pine type has been reported for the Jemez and Monzano Mountains, New Mexico (Castetter 1956). Layser has observed it on the Sandia Mountain Crest in New Mexico. Gehlbach (1967) reported a Douglas-fir/limber pine asociation from the Guadalupe Mountains "in the bowl at the head of Pine Spring Canyon."' Pearson (1920) stated, "limber pine is able to occupy windswept slopes and ridges where Douglas-fir will not grow." The series is recognized by Ellison (1954), Pfister (1972), Ream (1963), Society of American Foresters (1954), and Steele et al. (1975, 1977).

Pseudotsuga menziesii series.-The Pseudotsuga menziesii series is characterized by pure stands of Douglas-fir, or stands that appear codominant between Douglas-fir and ponderosa pine. True firs are notably absent, or at most accidental. Pinus strobiformis, quaking aspen, pinyon, junipers, and various oaks may be seral, or occur as understory components. At its upper distributional limits, the Pseudotsuga menziesii series commonly forms ecotones with $A$ bies concolor, Picea pungens, Pinus flexilis, Abies

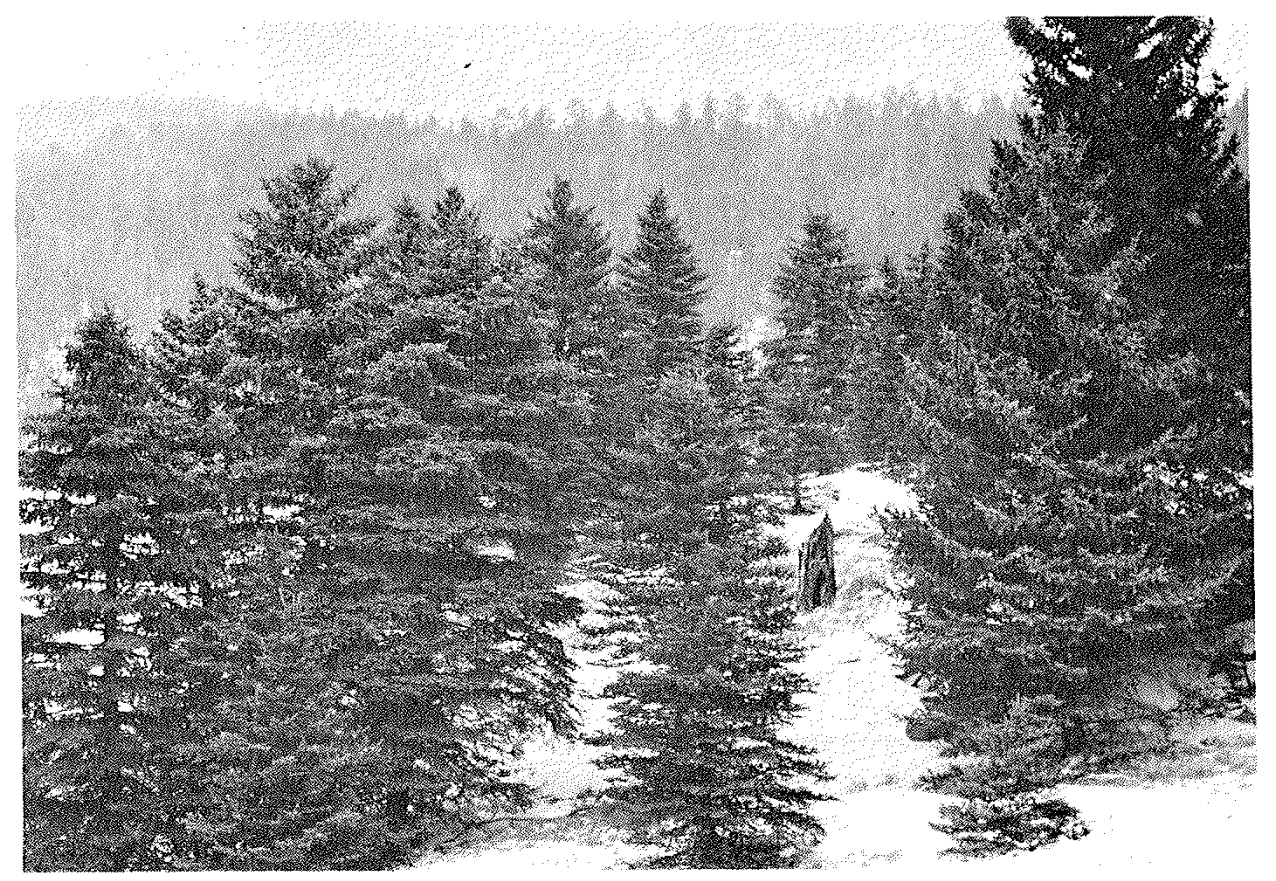

Figure 16. - Picea pungens series, Jemez Mountains, Santa Fe National Forest, New Mexico. 
lasiocarpa, or Picea engelmannii series. At its lower limits, it generally intergrades into ponderosa pine. The Douglas-fir series in the Southwest is recognizable in work by Brown and Lowe (1974), Castetter (1956), Kuchler (1964), Lindsley (1951), Moir and Ludwig (1977), and Pfister (1972).

Pinus ponderosa series.-The Pinus ponderosa series is generally dominated by the Rocky Mountain variety ( $P$. ponderosa var. scopulorum) of ponderosa pine (figs. 18, 19, and 20). Pinyon, junipers, and various oaks may occur in the understory. Quercus gambelii is often a long-lived seral species. The habitats comprising the ponderosa pine series are too warm and dry for Douglas-fir or true firs to occur.

The ponderosa pine series is complicated by the occurrence of $P$. ponderosa var. arizonica in southeastern Arizona. Where P. ponderosa var. arizonica is the dominant tree species, such as on the Catalina and Huachuca Mountains of Arizona (Wallmo 1955), evergreen oak, and Arbutus arizonica are often common in the understory. In general, the ponderosa pine series in the Southwest is more complex than has been described for the northern Rocky Mountains because of additional asociated tree species and the occurrence of two taxonomic varieties of ponderosa pine. Typically, Pinus ponderosa var. scopulorum occurs in pure stands on numerous plateaus and ranges of the Colorado Plateau and southern Rocky Mountains. The Pinus ponderosa series is described by Brown and Lowe (1974), Hanks et al. (1977), Lindsley (1954), Lowe (1964), Merkle (1962), Pearson $(1920,1931)$, and Society of American Foresters (1954).

Cupressus arizonica series.-The Cupressus arizonica series represents a topo-edaphic climax occurring in the Southwest only in southeastern and central Arizona (figs. 21 and 22). It occurs as relic stands restricted to north-facing slopes and canyon bottoms. Evergreen oaks are common components of the series. Tentatively, the series includes both C. a. glabra and C. a. arizonica, but additional study may show the former, a more northern variety, to be only a minor climax or seral species within other series; whereas, the southern variety $(C . a$ arizonica) represents relic climax situations. The series has been described by Brown and Lowe (1974) and Lowe (1964).

Pinus leiophylla series.-The series is represented by a heterogenous mixture of conifers and evergreen oaks (fig. 23). It is characterized by five-needle pines ( $P$. leiophylla, $P$. latifolia, and $P$. ponderosa var. arizonica) and evergreen oaks ( $Q$. arizonica, $Q$. emoryi, $Q$. hypoleucoides, and $Q$. reticulata). Pinus cembroides and Arbutus

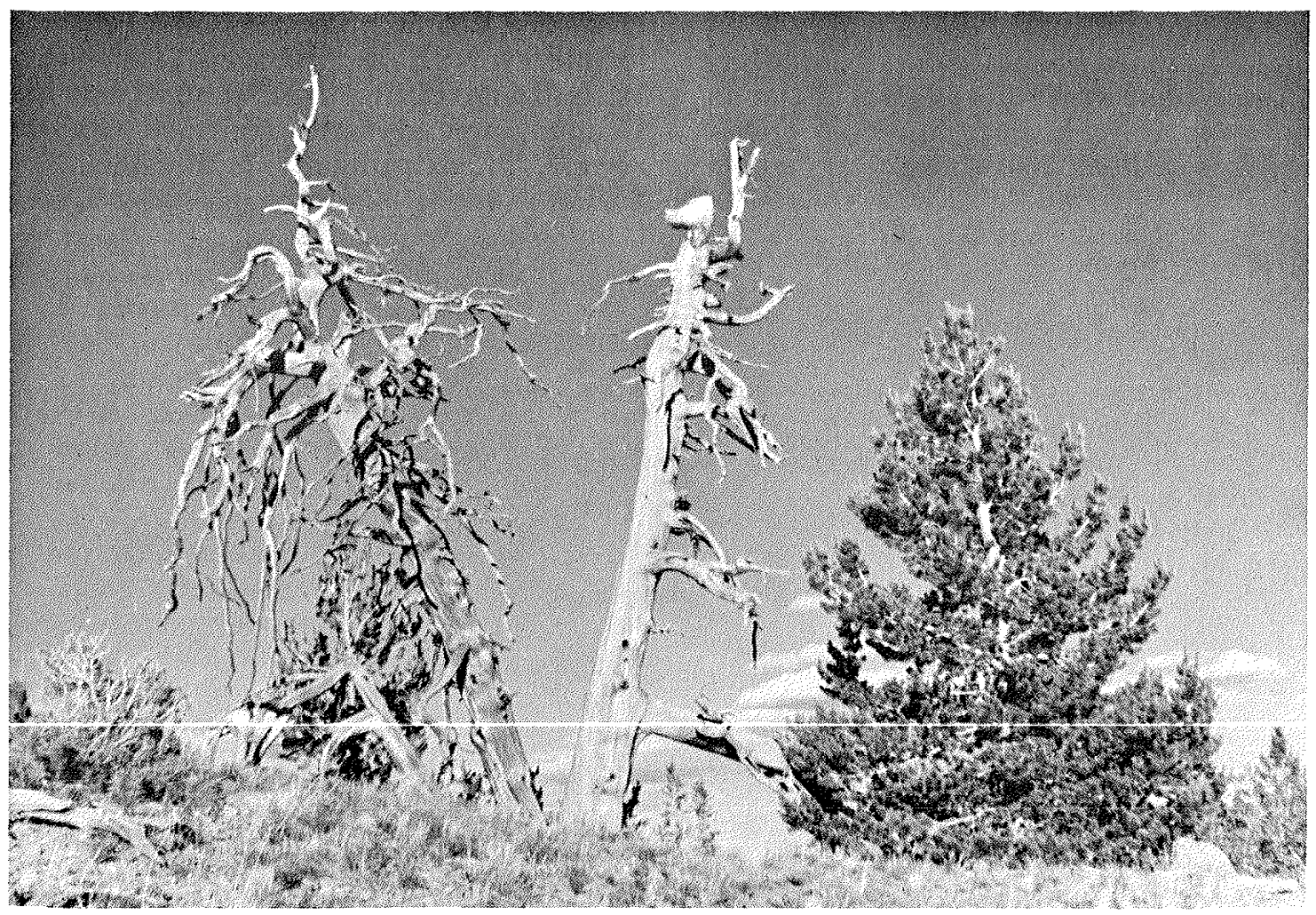

Figure 17.-Pinus flexilis series, Mt. Dutton, Utah. 


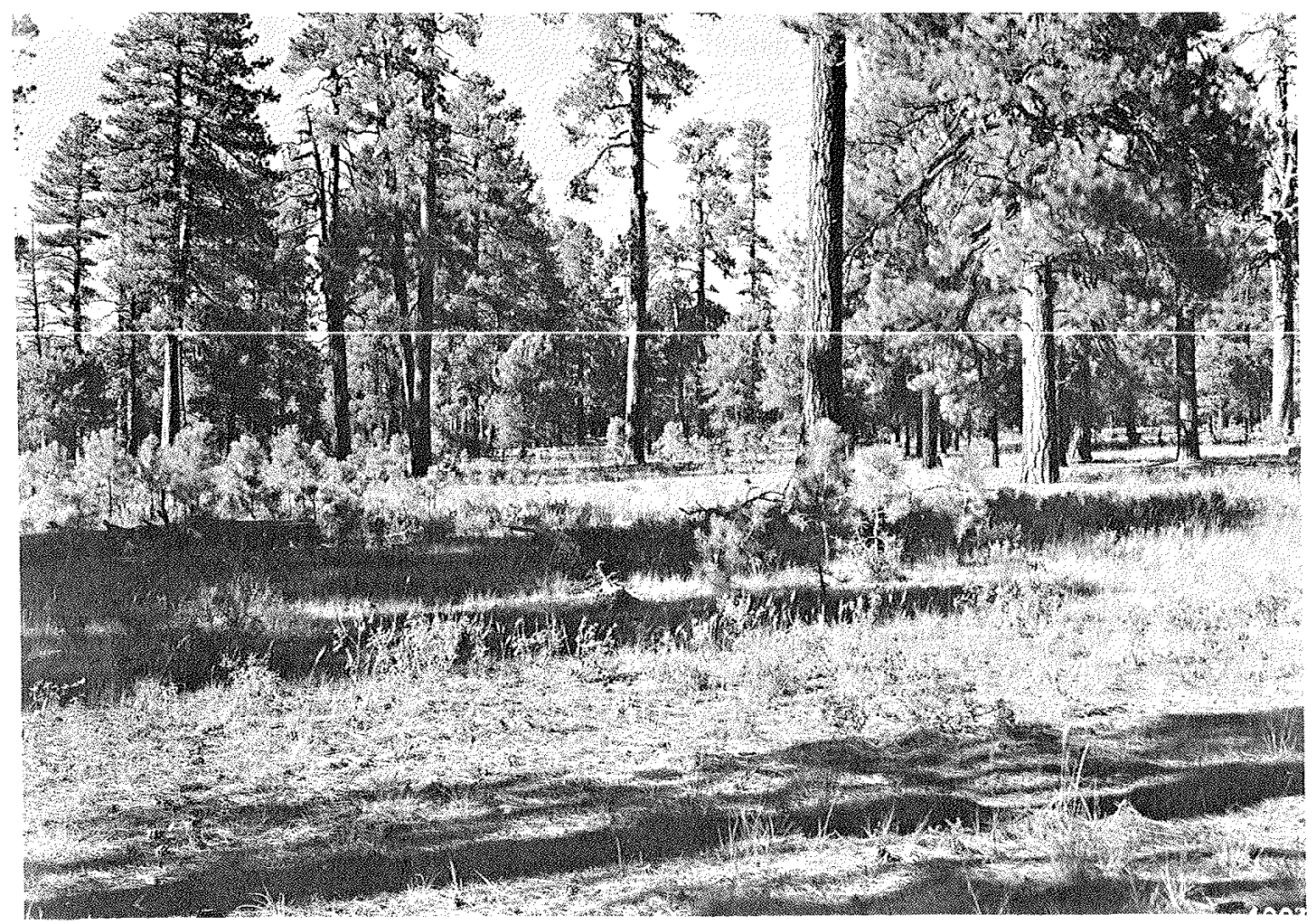

Figure 18.-Pinus ponderosa series, Coconino National Forest, Arizona.

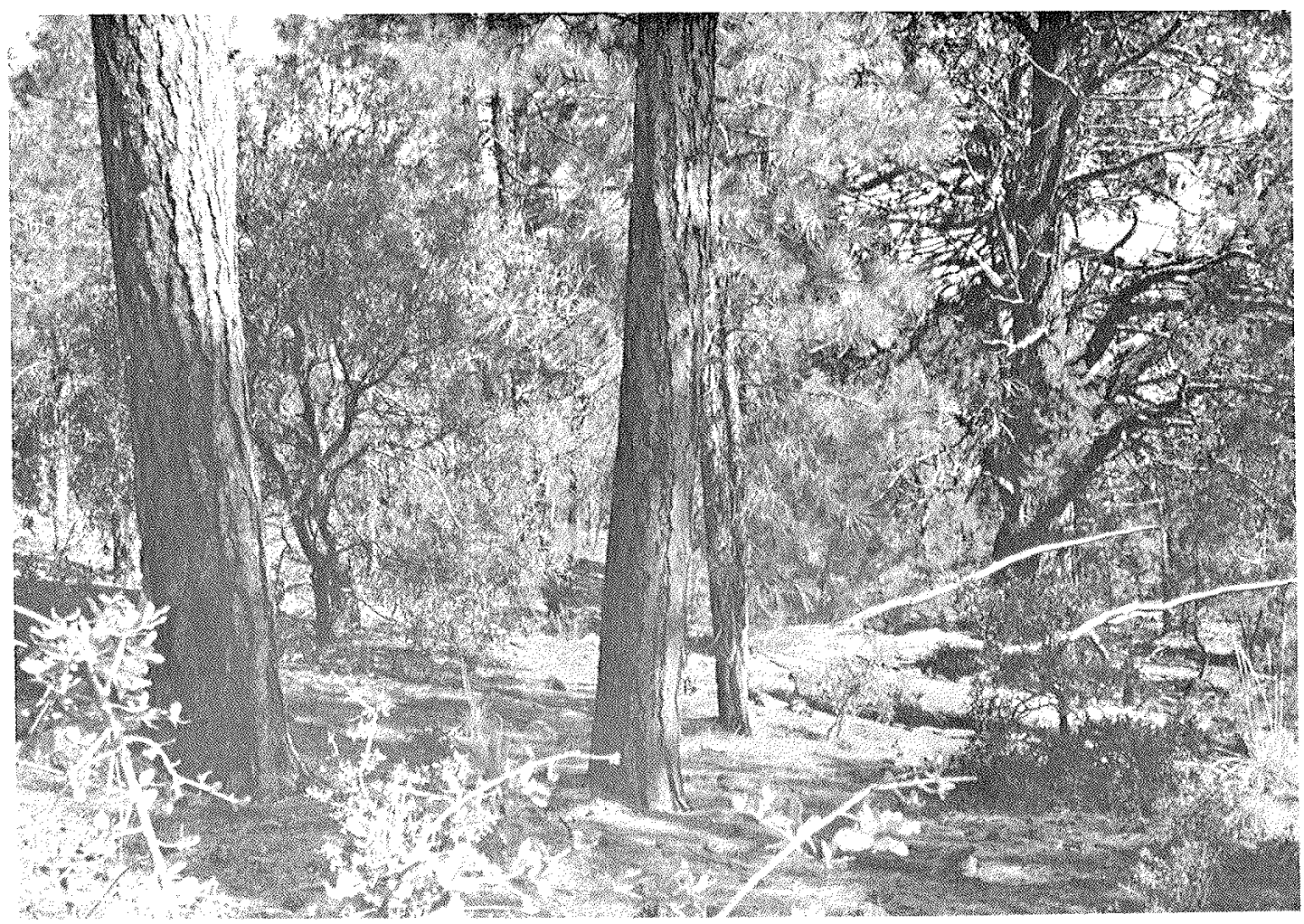

Figure 19. Pinus ponderosa series, Tonto Mational Forest, Arizona. The ponderosa pine series in the Southwest is often complicated by occurrence of subordinate tree species. 
arizonica are also present. Sufficient pines occur in this series to give it a different appearing aspect than woodland (Wallmo 1955). This series occurs only in southeastern Arizona and southwestern New Mexico in the Southwest, but it may be more extensive in Mexico. It has also been recognized by Brown and Lowe (1974).

Pinyon series-Pinyon series is characterized by the absence of conifers other than pinyon and junipers (figs. 24 and 25). The series includes those stands dominated by Pinus edulis, P. monophylla, or $P$. cembroides, or where those species are codominate with Juniperus spp. Pinus monophylla is reported to occur in pure stands at places (Harlow and Harrar 1950), and P. cembroides is confined to southeastern Arizona in the Southwest.

In the Guadalupe mountains, Juniperus deppena is reported to be the tree most frequently associated with $P$. edulis (Gehlbach 1967). Whereas, in northern New Mexico and northeastern Arizona, J. monosperma and $J$. scopulorum commonly occur (Howell 1941). J. osteosperma is often common in $P$. monophylla woodlands. It may also occur with $P$. edulis (Kesek 1966).

The different pinyon species and their respective associations represent different types of habitats, but because of the similarity in life form and climatic controls, they are grouped into one series for purposes of this paper. Future studies should provide bases to distinguish between environments supporting pinyon stands dominated by $P$. edulis or P. monophylla at the association level.

Brown and Lowe (1974) recognized a category for pinyon in which they included all Pinus edulis

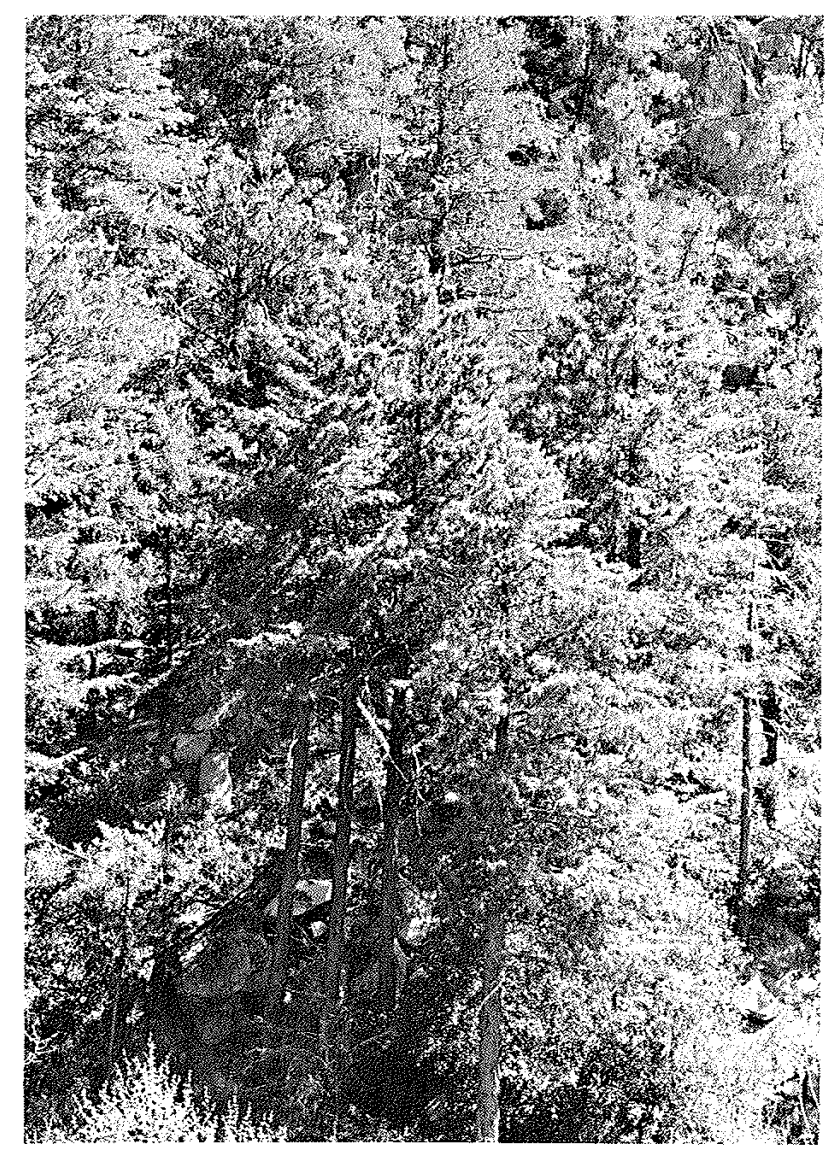

Figure 21.-Cupressus arizonica series on north slope of Bear Canyon, Catalina Mountains, Coronado National Forest.

Figure 20. - Pinus ponderosa series, Apache-Sitgreaves, Arizona, approaching the warm-dry end of the environmental gradient on which ponderosa pine is a climax dominant.

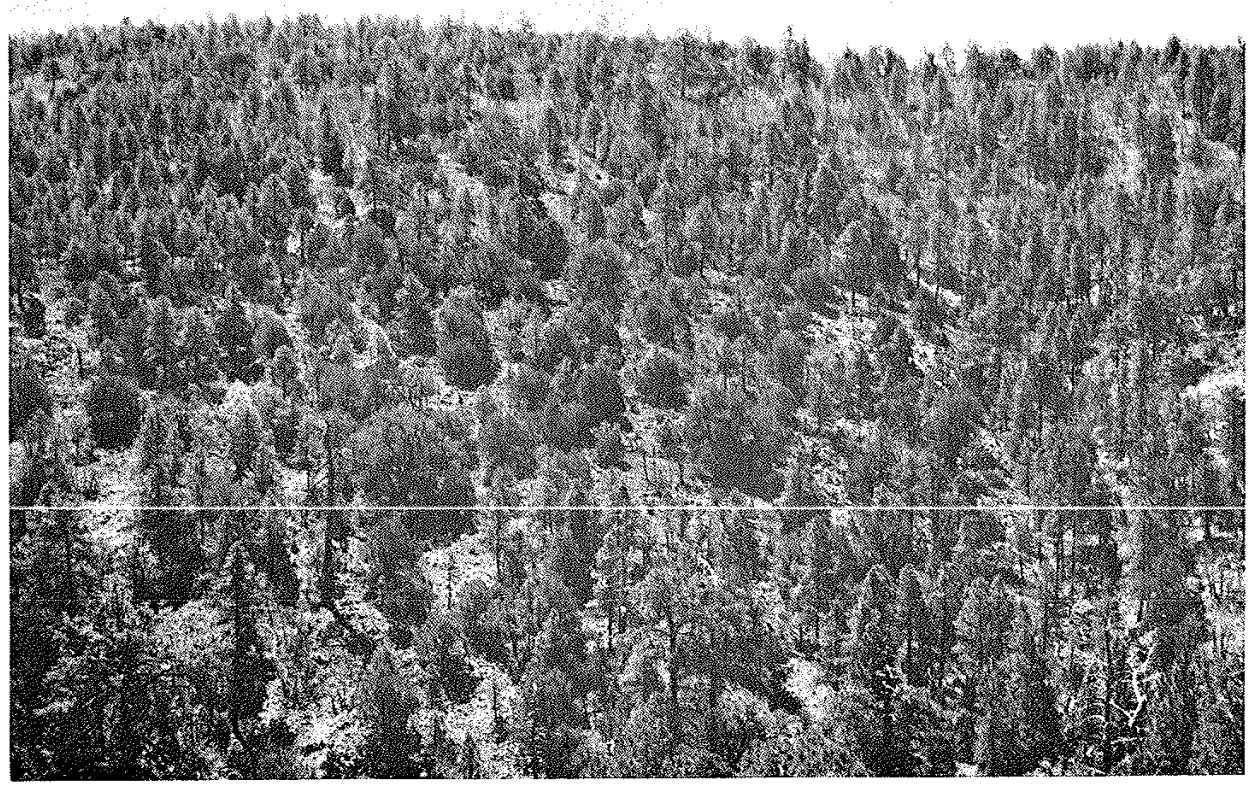


associations. For more discussion on the treatment of the pinyon-juniper complex see the Juniperus series discussion.

Juniperus series.-The Juniperus series, as proposed, is characterized by open stands of juniper (figs. 26 and 27). No other conifer is represented, or at most, pinyon or evergreen oak is widely scattered and confined to microsites. Woodlands dominated wholly or partially by junipers are widespread. Daubenmire (1943) recognized this type as a zone extending from Mexico to Canada. Traditionally, the coniferous woodlands have been lumped into an ubiquitious category called "pinyon-juniper" or "juniper-pinyon." The approach suggested here is that a logical break, consistent with the treatment of other series, is where pinyons successfully occupy the juniper woodlands, as compared to those communities where only junipers occur.

Literature and observations support this approach. Watson (1912) noted pinyon and juniper “. . . shade into each other very gradually, even imperceptibly, but no more so than ponderosa pine and Douglas-fir which are separated by the same authors," and, "Pinus edulis never extends as far down the mountain side as Juniperous monosperma, the difference being an average of 500 '." Merkle (1952) reported juniper to be the principal tree from 6,500 to 6,800 feet elevation in the Grand Canyon area, Arizona. Pearson (1920) also pointed out pinyon makes appearance at higher elevations than juniper.

In west central Arizona, J. californica is reported to occur only on alluvial fans below canyons, while in the same area, J. osteosperma and

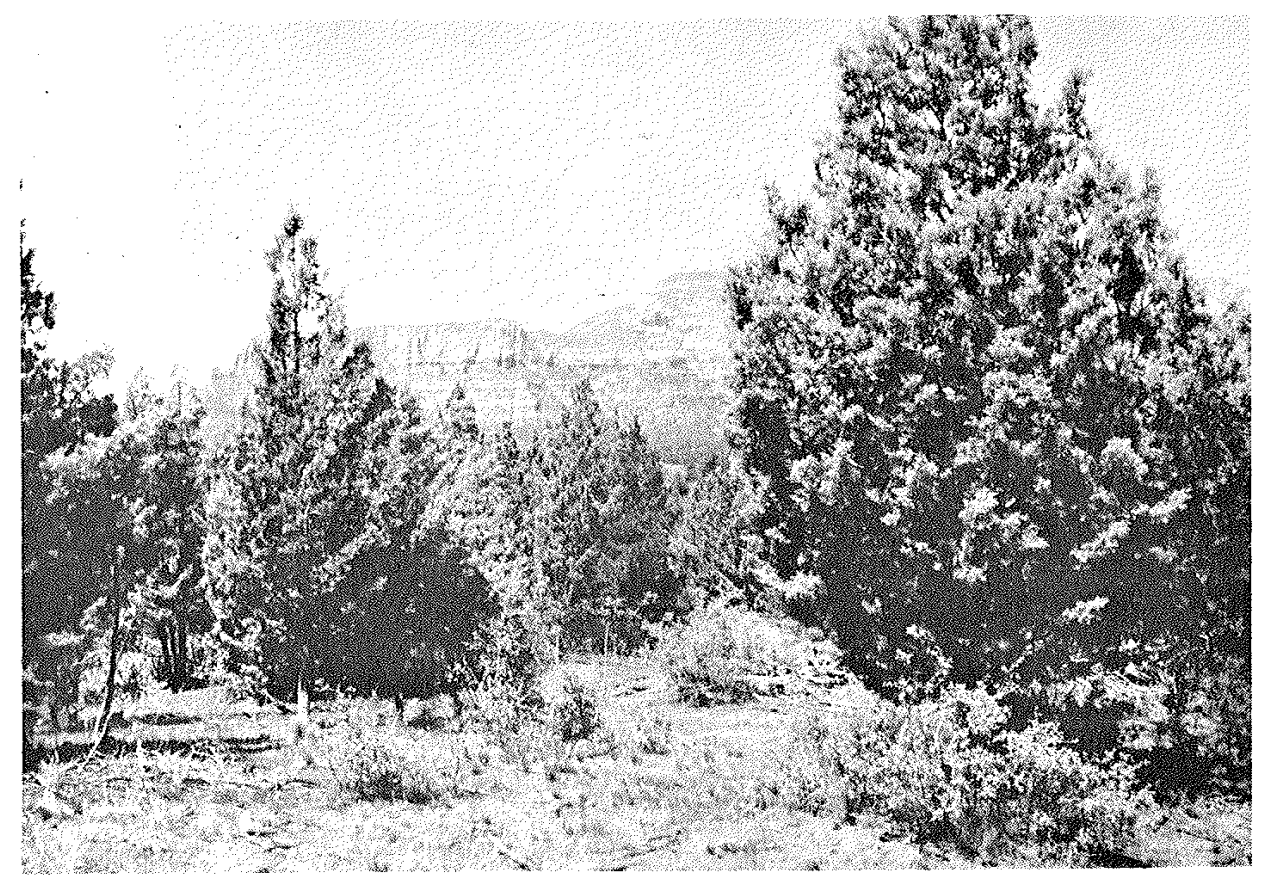

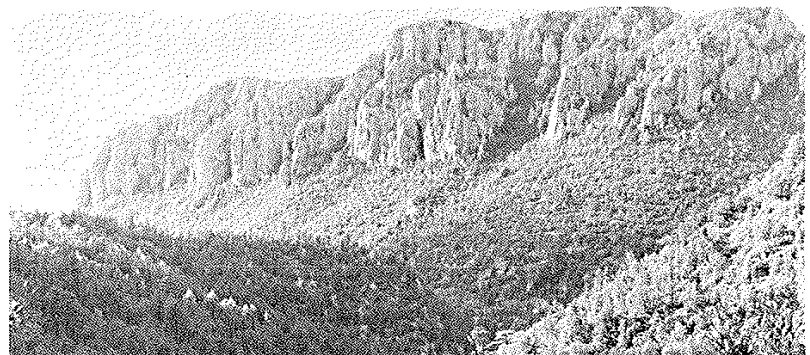

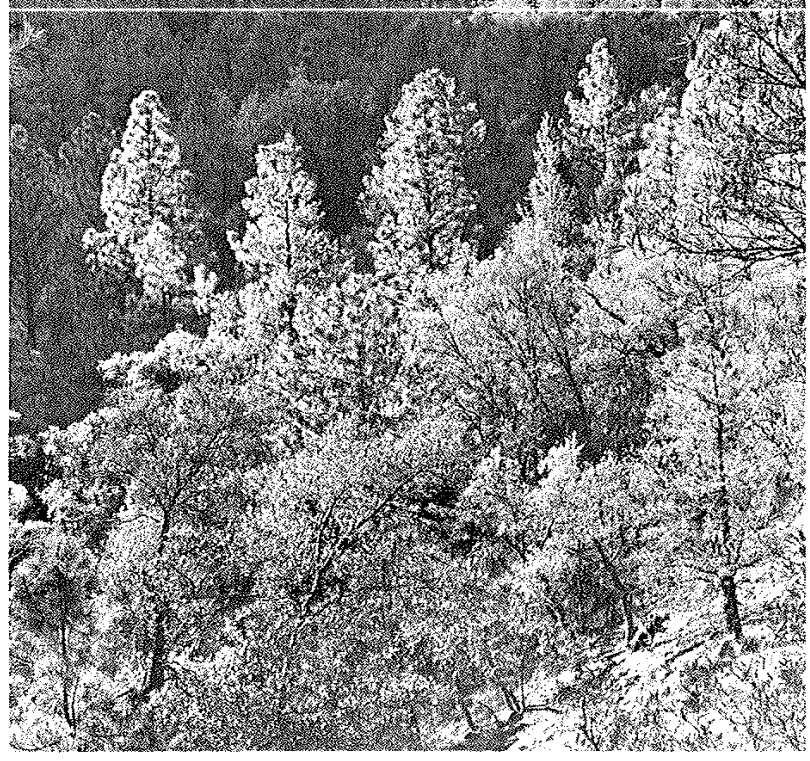

Figure 23. Pinus leiophylla series on Coronado National Forest, Arizona.
Figure 22. - Cupressus arizonica series, Coconino National Forest, near Sedona, Ariz. 


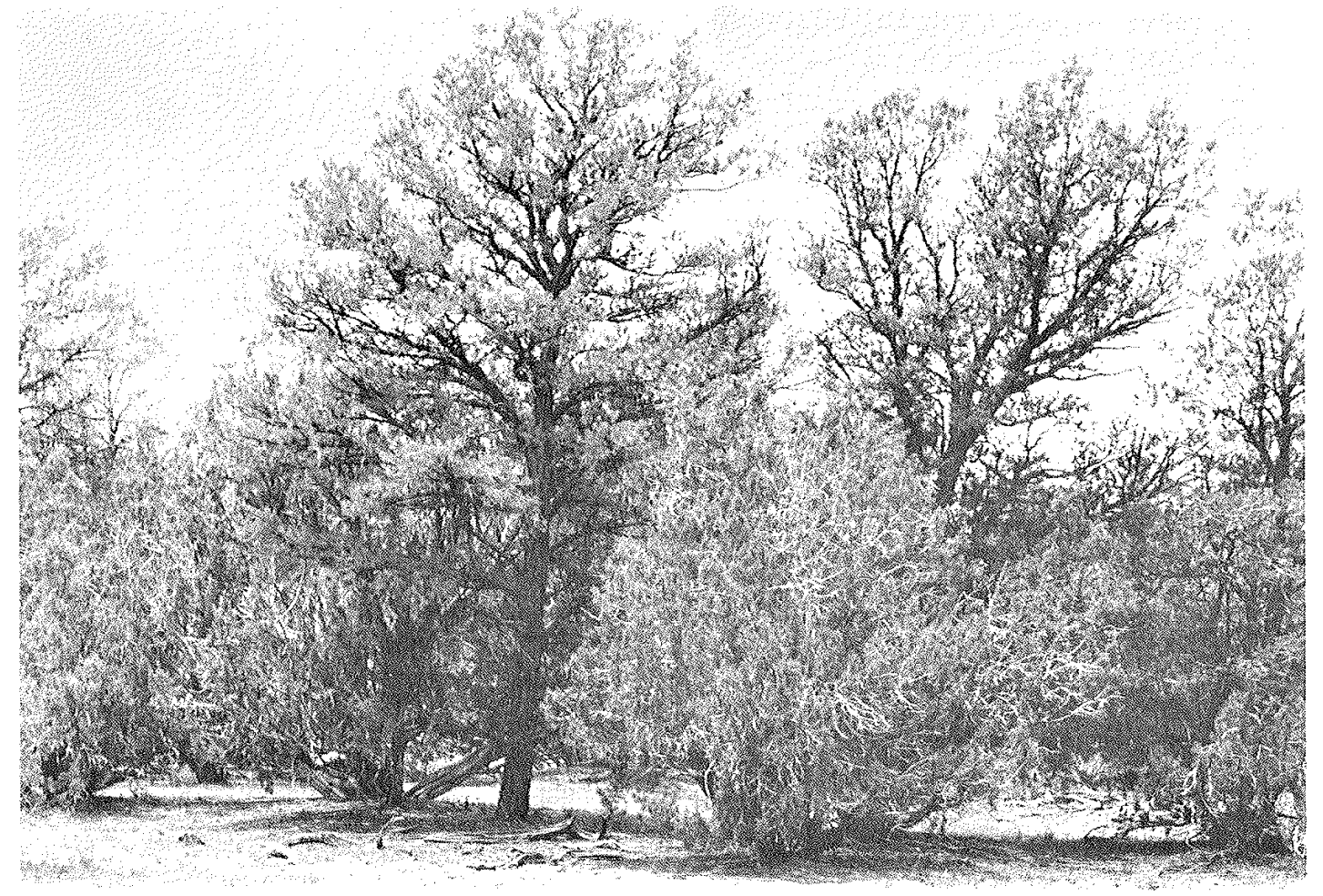

Figure 24.-Pinyon series on the Zuni Indian Reservation, Arizona.

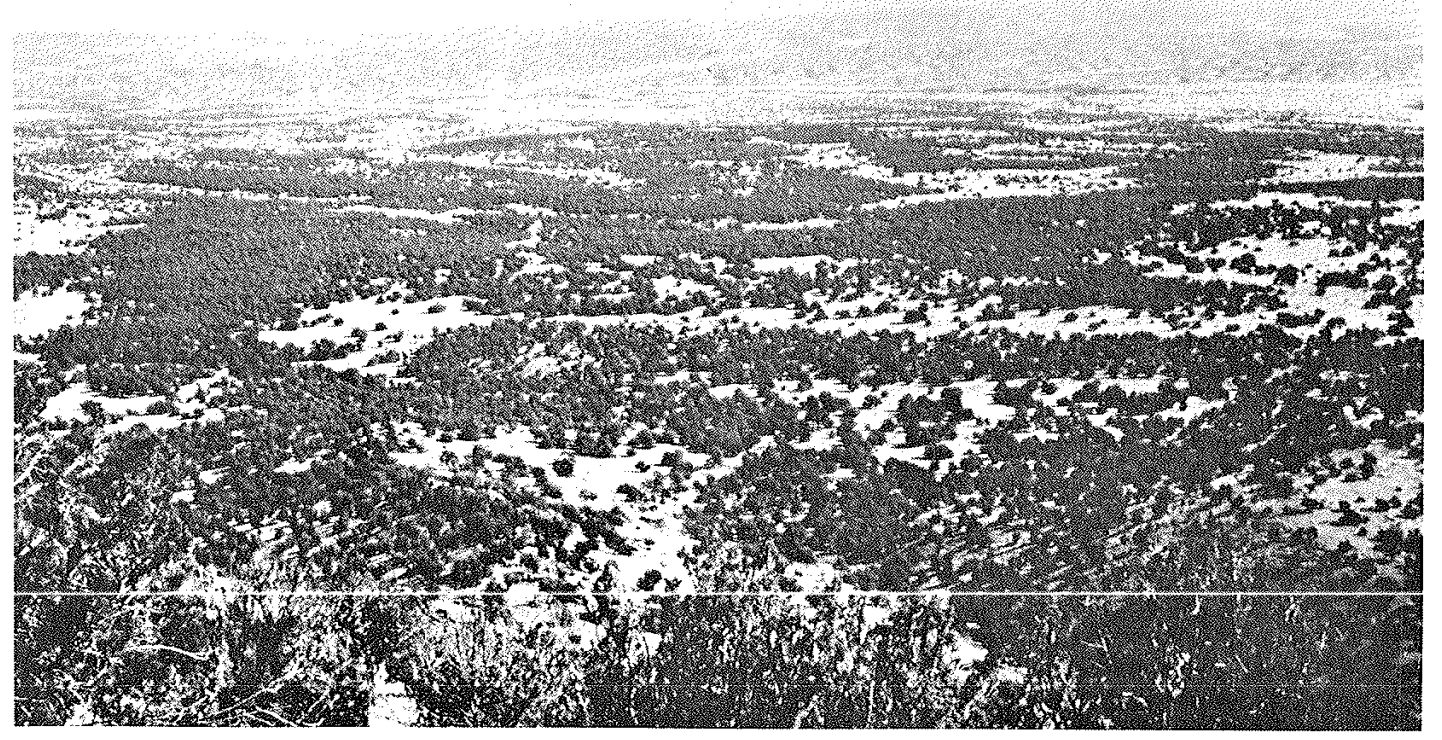

Figure 25.-Pinyon series, Santa Fe National Forest, New Mexico. 


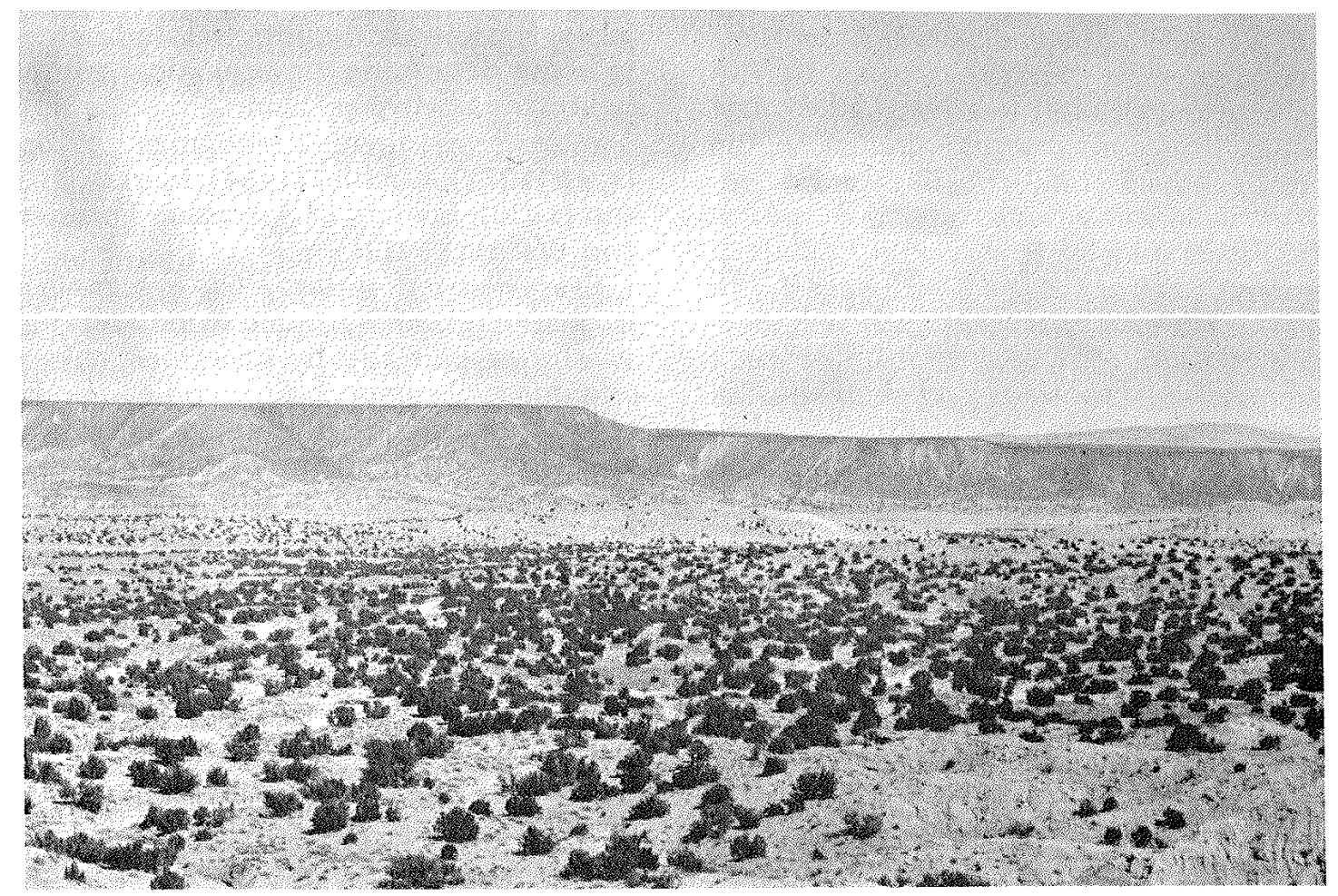

Figure 26. -Juniperus series near Albuquerque, N. Mex.

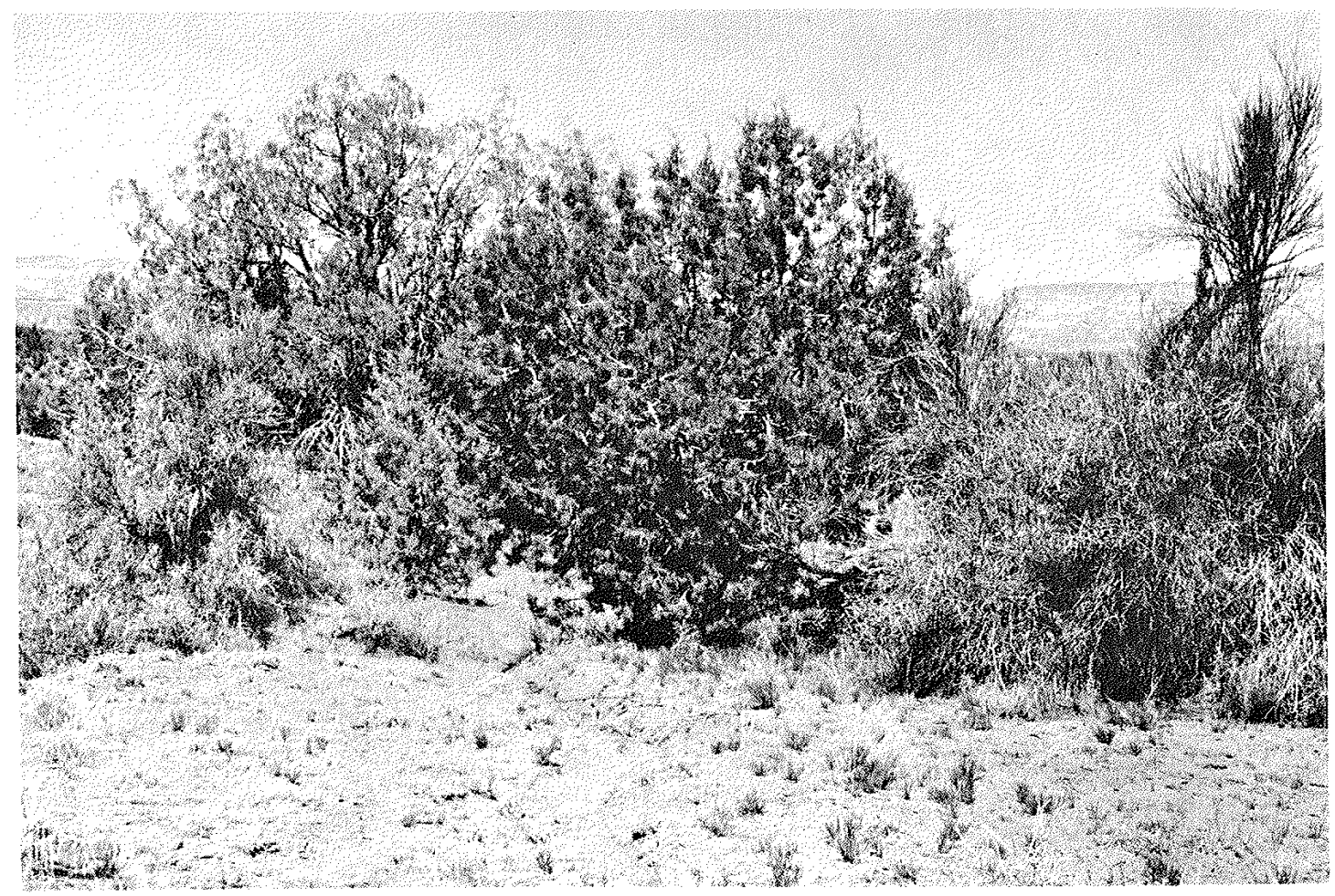

Figure 27.-Juniperus series with Juniperous osteosperma and Holacantha emoryi. The juniper species and associations comprising this series may vary, but generally it is recognizable from Mexico to Canada. 
Pinus monophylla are codominants in the canyonlands (Kesek 1966). J. monosperma is reported to dominate on rain-washed slopes in the Guadalupe escarpment, and to have the broadest ecological amplitude of any tree species in the Guadalupes (Gehlback 1967). J. deppena is reported to occupy wetter sites above J. monosperma, usually in association with Pinus edulis. J. pinchotii, a rare conifer for the Southwest (Little 1975), is not considered to be ecologically important because of its limited occurrence (Gehlbach 1967). Pearson (1920) reported that J. deppena has a higher moisture and lower temperature requirement than J. osteosperma and J. monosperma. On the basis of the literature, it appears relatively safe to say that, in New Mexico, much juniper-savanna is dominated by $J$. monosperma.

While Juniperus woodland (and savanna) is a readily recognizable physiognomy, it occurs over a wide range of environments.Six species of juniper occur in the Southwest. A center for distribution of juniper species in the Southwest is the Flagstaff area, where ranges of four species are sympatric (Whiting 1942). Some of the species' (e.g., J. osteosperma and $J$. deppena) ecological amplitudes are such that they do not appear to form monospecific stands in the Southwest, but are always in association with other conifers, evergreen oak, or other small trees. The literature indicates an ecological individuality exists between the various juniper species, but additional studies are required to better determine the ecological and habitat relationships between them.

Juniper woodland is recognized by Brown and Lowe (1974), Kuchler (1964), Merkle (1952), Pearsón (1920), Society of American Foresters (1954), and Watson (1912).

Evergreen oak series.-The evergreen oak series is characterized by open woodlands dominated wholly or partially by evergreen oaks (Quercus arizonica, Q. emoryi, Q. hypoleucoides, and Q. oblongifolia), sometimes in association with Juniperous deppena and/or J. monosperma, and at places Pinus cembroides (fig. 28). The series is not to be confused with seral stands of oaks (Quercus hypoleucoides, and $Q$. reticulata) that may sometimes occur on conifer sites (Wallmo 1955) or evergreen oak scrubland.

Occurrence of evergreen oak species is stratified altitudinally (Lowe 1961). Wallmo (1955) reported that the lowest elevational type of oak woodlands in the Huachuca Mountains, Arizona, are dominated by $Q$. oblongifolia (at 5,000 feet and seldom above 5,200 feet). It is soon joined by $Q$. emoryi and $Q$. arizonica. At 5,200 feet $Q$. hypoleucoides appears. J. deppena is reported to be the most common species of juniper throughout the oak woodlands in the Huachuca Mountains. In parts of New

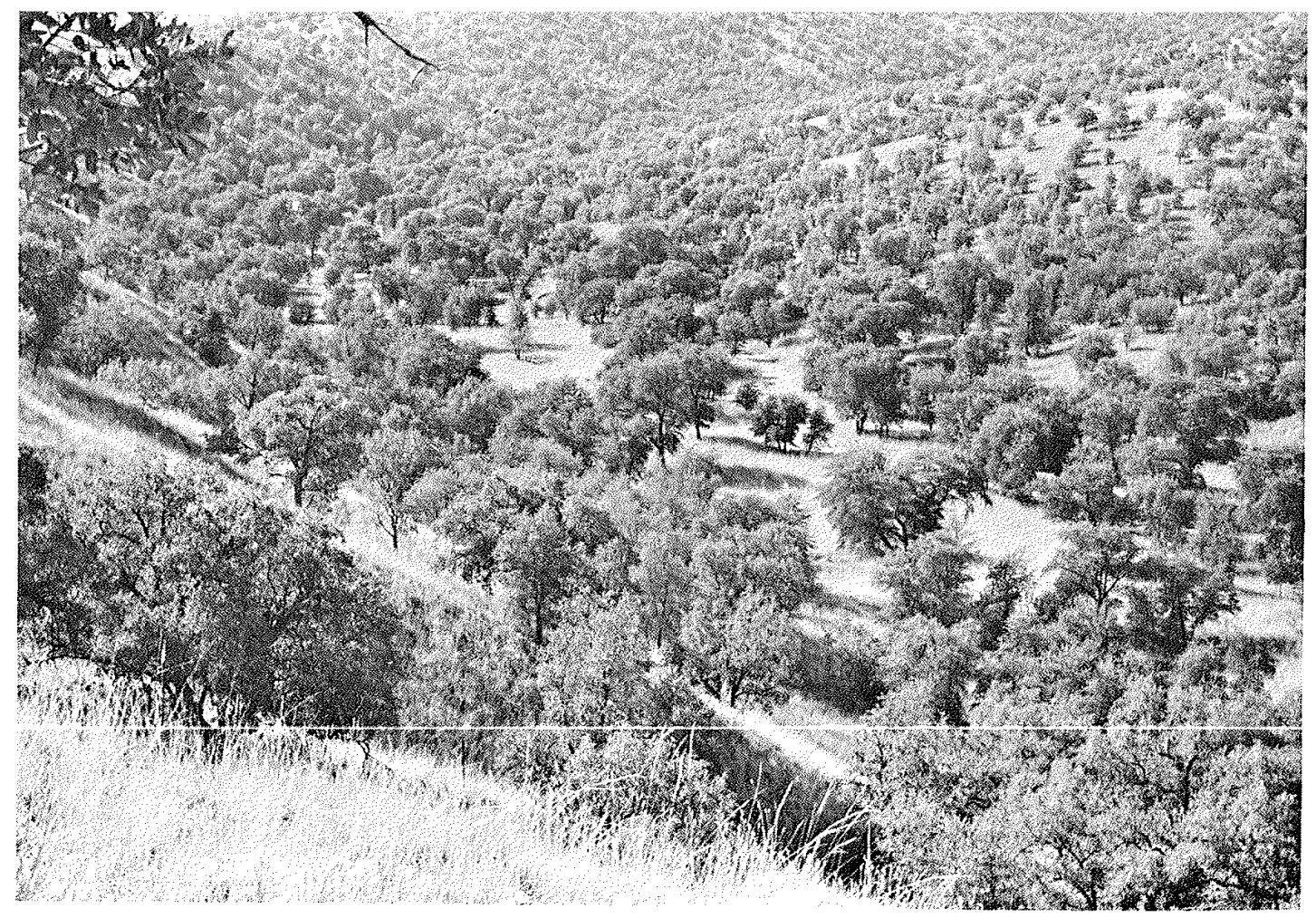

Figure 28.-Evergreen oak woodland series in southeastern Arizona. 
Mexico, Q. grisea may be an important component of evergreen oak woodlands (Dick-Peddie and Moir 1970, Gehlbach 1967). Evergreen oak woodlands are described in part by Dick-Peddie and Moir (1970), Gehlbach (1967), Lowe (1964), Shreve (1942), Society of American Foresters (1954), Wallmo (1955), and Whittaker and Niering (1975).

Deciduous broad-leaved forest.-Deciduous forest in the Southwest may be divided into several types. The first is forest dominated by one or more of the following species: Fraxinus velutina, Juglans major, Platanus wrightii, Populus fremontii, and Salix bonpladiana (Lowe 1964). Generally, these forests are confined to major river bottoms, canyons, and floodplains. At least three series appear to be represented in this group.

Other riparian forests (or woodlands) may be dominated by Acer, Alnus, Morus, Prosopis, Prunus, Populus augustifolia, and/or Salix. Additional study will be required to determine climax and successional relationships within these latter types. Classification of riparian forests in the Southwest has been discussed in more detail by Pase and Layser (1977).

Another type of deciduous broad-leaved forest appears in southeastern New Mexico where Quercus muhlenbergii seems to be a climax dominant in local situations confined to mountain canyons.

A common deciduous forest type in the Southwest is Populus tremuloides (fig. 29). The successional role of aspen has long been open to debate (Pfister 1972). Where it is associated with Pseudotsuga, Abies concolor, or Abies lasiocarpa, it is clearly a seral species. However, there are situations where Populus tremuloides appears in relatively stable stands without conifer regeneration, and it has been proposed as climax in certain edaphic situations (Hoffman and Alexander 1976, Pfister 1972, Reed 1971, and Severson and Thilenius 1976). There is a clear opportunity for an aspen series in the Southwest when criteria for separating seral and climax aspen stands are described. The possibility for aspen to form edaphic climaxes is indicated by the broken heavy line in figure 9.

\section{Computer Compatibility}

The timber and range subsystem of INFORM ${ }^{8}$ both require vegetation classification information for the PLANT-ASSOC table. This table is a threepart field (table 2). The first part consists of two columns where the subformation information

\footnotetext{
8Information for management (INFORM) is a system being developed by the USDA Forest Service to aid managers in data storage, retrieval, and analysis (Forest Service Manual 1390).
}

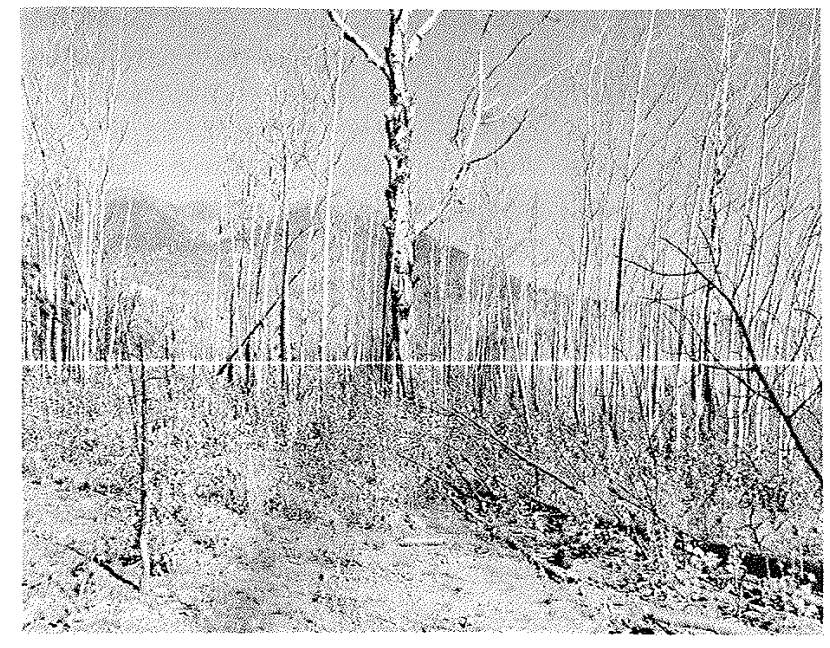

Figure 29.-Aspen stand, San Francisco Peaks, Arizona. Criteria for separating seral from long-lived, stable aspen communities needs to be described.

Table 2.-Shows example of the field and columns into which the hierarchical classification information could be loaded

\begin{tabular}{ccc}
\hline Field 1 & Field 2 & Field 3 \\
$\begin{array}{c}\text { Col. } 1 \text { Col. } 2 \\
\text { Subformation }\end{array}$ & $\begin{array}{c}\text { Col. } 1 \text { Col. } 2 \\
\text { Series }\end{array}$ & $\begin{array}{c}\text { Col. } 1 . \quad \text { Col. } 2 \text { Col. } 3 \\
\text { Associaton }\end{array}$ \\
\hline
\end{tabular}

could be loaded, providing room for 99 subformations. The second field is also two-part, so that up to 99 series could be loaded for any one subformation. The third part of the field contains a threecolumn entry for association or community type. This has the potential for 999 associations of a particular subformation and series being loaded. Retrieval of stored data from the system can be for all PLANT-ASSOC fields or for any one part. The approach is systematic and hierarchical, and allows for incorporation of additional data as the plant classification system evolves (table 3 ).

The data storage approach, as well as the classification method and categories, are wholly compatible and consistent with land classification and information systems-such as Modified ECOCLASS, ${ }^{9}$ ECOSYM (Davis and Henderson 1976), Brown and Lowe (1974), or any others which could be utilized for national assessments under the Renewable Resources Planning Act of 1974.

${ }^{9}$ Gallaher, W. B., and Committee (draft). Modified ECOCLASS-A method for classifying ecosystems. USDA Forest Service, Rocky Mountain and Southwestern Regions. Mimeo, October 1, 1975. 
Table 3.-Shows the classification categories and examples of how computer codes could be assigned for the timber subsystem of INFORM

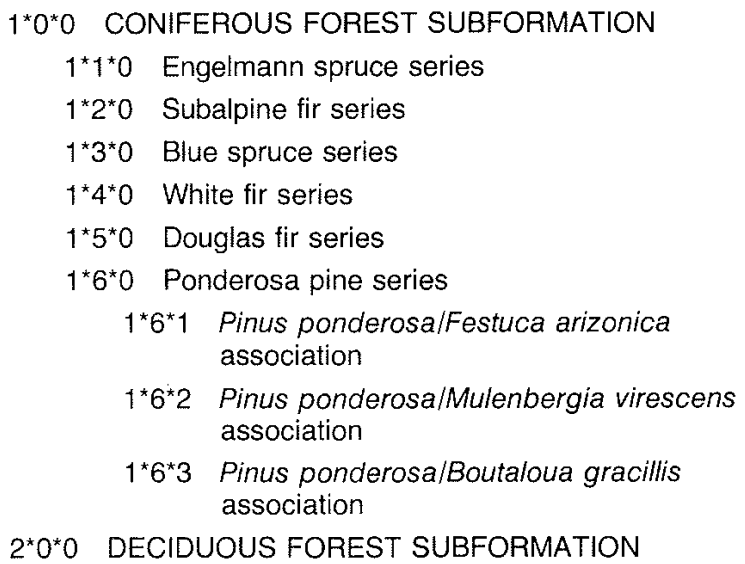

\section{SUMMARY AND CONCLUSIONS}

This paper demonstrates how a preliminary classification for all natural vegatation in the Southwest might be accomplished to the series level with little additional research. Research by Hanks et al. (1977) and Moir and Ludwig (1979) will contribute to the classification of forest vegetation to the association level. Recent state-of-theart papers on silviculture (Alexander 1974, Jones 1974, and Schubert 1974) have all identified the development and employment of habitat type classification as necessary to assure proper management of forests and sites in the southern Rocky Mountains.

Considerable additional research is needed to complete the classification at the association level for other than forest vegetation. However, concepts and methods to do this, as well as resulting applications to land management, are similar to those for forest vegetation (Daubenmire 1970, Hironaka 1977, and Shiflet 1973).

The method applied here, and proposed for the continued development of the classification, is described by Poore (1962). It consists of development of the classification through successive approximation by progressively more detailed investigations being conducted within a main framework.

Other research needs are suggested by this study. They are determining the successional and ecological relationships between: Pinus strobiformis and P. flexilis, Abies lasiocarpa lasiocarpa and $A$. 1 . arizonica, Picea engelmannii and $P$. pungens, Cupressus arizonica arizonica and C. $a$. glabra, and Pinus ponderosa scopulorum and P. p. arizonica. In addition, information on the successional and synecological roles of various junipers, oaks, and locust in forest stands is generally lacking. For example, tree growth in the Midwest has been found to be better on sites previously occupied by black locust because of improved soil structure and more foliar nitrogen (Carmena et al. 1976); does New Mexico locust play a similar successional role in the Southwest?

The classification approach proposed is computer compatible, and can be used with existing information systems such as INFORM. Since the method is systematic and hierarchical in design, it will allow incorporation of new or additional information as the vegetation classification system evolves.

If phytosociological studies are pursued by the methods suggested here, the plant associations for the Southwest eventually will be described systematically, their diagnostic species concisely defined, and their habitat, succession, and management implications described in detail.

Standardization of concepts and methods, as proposed here, is a major advantage, making the work of one author directly interpretable by, and useful to, another. Research findings reported within the site-based classification system will make those results more meaningful to management.

Development of a vegetative classification system, with concurrent training of personnel in its use, can result in a strong land management tool that expands knowledge about the forest and range and allow application of practices and prescriptions with due regard for environmental situations.

\section{LITERATURE CITED}

Alexander, Robert R. 1973. Partial cutting in oldgrowth spruce-fir. USDA For. Serv. Res. Pap. RM-110, 16 p. Rocky Mt. For. and Range Exp. Stn., Fort Collins, Colo.

Alexander, Robert R. 1974a. Silviculture of central and southern Rocky Mountain forests: A summary of the status of our knowledge by timber types. USDA For. Serv. Res. Pap. RM-120, 36 p. Rocky Mt. For. and Range Exp. Stn., Fort Collins, Colo.

Alexander, Robert R. 1974b. Silviculture of subalpine forests in the central and southern Rocky Mountains: The status of our knowledge. USDA For. Serv. Res. Pap. RM-121, 88 p. Rocky Mt. For. and Range Exp. Stn., Fort Collins, Colo.

Bailey, R. G., R. D. Pfister, and J. A. Henderson. 1978. The nature of land and resource classification. J. For. 76:650-655

Brown, D. 1973. The natural vegetative communities in Arizona. (map). Ariz. Res. Info. Syst. Phoenix, Ariz. 
Brown, D., and C. Lowe, 1974. A digitized computer-compatible classification for national and potential vegetation in the Southwest with particular reference to Arizona. Ariz. Acad. Sci. Vol. 9, Supp. 2:11.

Brown, David E., Charles H. Lowe, and Charles P. Pase. 1977. Biotic communities of the Southwest. USDA For. Serv. Gen. Tech. Rep. RM-41. (map). Rocky Mt. For. and Range Exp. Stn., Fort Collins, Colo.

Carmena, W. H., F. B. Clark, R. D. Williams, and P. R. Hannah. 1976. Hardwoods planted in old fields favored by prior tree cover. USDA For. Serv. Res. Pap. NC-134, 16 p. North Cent. For. and Range Exp. Stn., St. Paul, Minn.

Castetter, E. F. 1956. The vegetation of New Mexico. N. Mex. Q. 26:257-288.

Clements, Federick E. 1920. Plant indicators-the relation of plant communities to process and practice. Carnegie Inst. Wash. Publ. 200, 373 p. Gibson Bros. Press, Inc., Wash., D.C.

Clements, Federick E. 1936. Nature and structure of the climax. J. Ecol. 23:252-284.

Cooper, C. F. 1960. Changes in vegetation, structure, and growth of southwestern pine forest since white settlement. Ecol. Monogr. 30:129164.

Cooper, S. V. 1975. Forest habitat types of northwestern Wyoming and contiguous portions of Montana and Idaho. Ph.D. thesis. Wash. State Univ., Pullman. 190 p.

Daubenmire, R. 1943. Vegetational zonation in the Rocky Mountains. Bot. Rev. 9:325-393.

Daubenmire, R. 1968. Plant communities. Harper and Row, New York. 300 p.

Daubenmire, R. 1970. Steppe vegetation of Washington.Wash. Agric. Exp. Stn. Tech. Bull. $62,131 \mathrm{p}$.

Daubenmire, R. 1973. A comparison of approaches to the mapping of forest land for intensive management. For. Chron. 49:87-91.

Daubenmire, R. 1976. The use of vegetation in assessing the productivity of forest lands. Bot. Rev. 42:115-143.

Daubenmire, R., and Jean B. Daubenmire. 1968. Forest vegetation of eastern Washington and northern Idaho. Wash. Agric. Exp. Stn. Tech Bull, 60, 104 p.

David, L. S., and J. A. Henderson. 1976. ECOSYM, progress report 1 . A classification and information system for management of wildland ecosystems: The conceptual framework. Dep. For. and Outdoor Recreat., Utah State Univ., Logan. $55 \mathrm{p}$.

Dick-Peddie, W.A., and W. H. Moir. 1970. Vegetation of the Organ Mountains, New Mexico. Colo. State Univ. Range Sci. Dep.,Sci. Sericomo $4: 1-28$.
Dixon, H. 1935. Ecological studies on the high plateaus of Utah. Bot. Gaz. 97:272-320.

Dyksterhuis, E. J. 1957. The savannah concept and its use. Ecology 38:435-442.

Ellison, L. 1954. Subalpine vegetation of the Wasatch Plateau, Utah. Ecol. Monogr. 24:84-184.

Ford-Robertson, F. E.. (ed.) 1971. Terminology of forest science technology practice and products. 349 p. Washington, D.C.

Freeman, C. E., and W. A. Dick-Peddie. 1970. Woody riparian vegetation in the Black and Sacramento Mountain ranges, southern New Mexico. Southwest. Nat. 15:145-164.

Gehlbach, Frederick R. 1967. Vegetation of the Guadalupe Escarpment, New Mexico-Texas. Ecology 48:404-419.

Graham, S. A. 1941. Climax forests of the upper penninsula of Michigan. J. Ecol. 22:355-362.

Hall, F. C. 1973. Plant communities of the Blue Mountains in eastern Oregon and southeastern Washington. USDA For. Serv. Publ. 8200-1, 62 p. Pac. Northwest Reg. (R-6), Portland, Oreg.

Hanks, J., and W. A. Dick-Peddie. 1974. Vegetation patterns of the White Mountains, New Mexico. Southwest. Nat. 18:371-382.

Hanks, J. P., E. L. Fitzhugh, and S. R. Hanks. 1977. Preliminary habitat types and community types in the ponderosa pine forests of northern Arizona. USDA For. Serv., Southwest. Reg., Albuquerque, N. Mex. 143 p. [Mimeo.]

Hanley, D. P., W. Schmidt, and G. Blake. 1975. Stand structure and successional status of two spruce-fir forests in southern Utah. USDA For. Serv. Res. Note INT-176, 16 p. Intermt. For. and Range Exp. Stn., Ogden, Utah.

Hanson, Herbert C. 1924. A study of the vegetation of northeastern Arizona. Nebr. Univ. Stud. 24:85-178.

Harlow, William M., and Ellwood S. Harrar. 1950. Textbook of dendrology. 3rd ed. $555 \mathrm{p}$. McGraw-Hill Book Co., Inc. New York, Toronto, London.

Hironaka, M. 1977. Habitat-type classification for grasslands and shrublands of southern Idaho, second year's report. Coll. For., Wildl. and Range Sci., Univ. Idaho, Moscow, 38 p. [Mimeo]

Hoffman, G. R., and R. R. Alexander. 1976. Forest vegetation of the Bighorn Mountains, Wyoming: A habitat type classification. USDA For. Serv. Res. Pap. RM-170, 38 p. Rocky Mt. For. and Range Exp. Stn., Fort Collins, Colo.

Howell, Joseph, Jr. 1941. Pinyon and juniper woodland of the Southwest. J. For. 39:542-545.

Jones, John R. 1974. Silviculture of southwestern mixed conifers and aspen: The status of our knowledge. USDA For Serv. Res. Pap. RM-122, 44 p. Rocky Mt. For. and Range Exp. Stn., Fort Collins, Colo. 
Kesek, F. C. 1966. The distribution and taxonomy of three western junipers. Brittonia 18:350-372.

Kuchler, A. W. 1964. Potential natural vegetation of the conterminous United States. Am. Geogr. Soc. 36. New York.

Kuchler, A. W. 1967. Vegetation mapping. Ronald Press Co., New York. 472 p.

Kuchler, A. W. 1973. Problems in classifying and mapping vegetation for ecological regionalization. Ecology 54:512-523.

Korstian, C. F. 1917. The indicator significance of native vegetation in the determination of forest sites. Plant World 10:267.

Layser, E. F. 1974. Vegetative classification: Its applications to forestry in the Northern Rocky Mountains. J. For. 72:354-357.

Little, Elbert L., Jr. 1950. Southwestern trees: A guide to the native species of New Mexico and Arizona. U.S. Dep. Agric., Agric. Handb. 9, 109 p.

Little, Elbert L., Jr. 1971. Atlas of United States trees: Vol. 1, Conifers and important hardwoods. USDA For. Serv. Misc. Publ. 1146, 9 p. +202 maps.

Little, Elbert L., Jr. 1975. Rare and local conifers in the United States. USDA For. Serv. Conserv. Res. Pap. 19, Wash., D.C.

Little, Elbert L., Jr. 1976. Atlas of United States trees: Vol. 3. Minor western hardwoods. USDA For. Serv. Misc. Publ. 1314, 13 p. +213 maps. Wash., D.C.

Lindsley, A. A. 1951. Vegetation and habitats in a southwestern volcanic area. Ecol. Monogr. 21:227-253.

Lowe, Charles H., Jr. 1961. Biotic communities in the sub-Mogollon region of the inland Southwest. J. Ariz. Acad. Sci. 2(1):40-49.

Lowe, Charles H., Jr. 1964. Arizona's natural environment. Univ. Ariz. Press, Tucson. 135 p.

Lowe, Charles H., Jr., and D. E. Brown. 1973. The natural vegetation of Arizona. A.R.I.S. Coop. Publ. 2, 53 p. + map.

Merkle, John. 1952. An analysis of a pinyonjuniper community at Grand Canyon, Arizona. Ecology 33:375-384.

Merkle, John. 1954. An analysis of the spruce-fir community on the Kaibab Plateau, Arizona. Ecology 35:316-322.

Merkle, John. 1962. Plant communities of the Grand Canyon Area, Arizona. Ecology 43:698711.

Merriam, C. Hart. 1890. Results of a biological survey of the San Francisco Mountain region and desert of the Little Colorado in Arizona. U.S. Dep. Agric., Bur. Biol., Surv. Am. Fauna 3, 136 p.

Merriam, C. Hart. 1898. Life zones and crop zones of the United States. U.S. Dep. Agric., Bur. Biol., Surv. Am. Fauna 3, 136 p.
Moir, W. H., and J. A. Ludwig. 1977. A preliminary classification of spruce-fir and mixed conifer forest habitat types in Arizona and New Mexico. Biol. Dep., N. Mex. State Univ., Las Cruces. 373 p. [Mimeo.]

Moir, William H., and John A. Ludwig. 1979. A classification of spruce-fir and mixed conifer habitat types of Arizona and New Mexico. USDA For. Serv. Res. Pap. RM-207, 47 p. Rocky Mt. For. and Range Exp. Stn., Fort Collins, Colo.

Nichol, A. A. 1937. The natural vegetation of Arizona. Ariz. Agric. Exp. Stn. Tech. Bull. 6:181-122.

Nichol, A. A. 1952. The natural vegetation of Arizona. Ariz. Agric. Exp. Stn. Tech. Bull. 127:185-230.

Pase, C. P., and E. F. Layser. 1977. Classification of riparian habitat in the Southwest. p. 5-9. In Importance, preservation and management of riparian habitat: A symposium. USDA For. Serv. Gen. Tech. Rep. RM-43. Rocky Mt. For. and Range Exp. Stn., Fort Collins, Colo.

Pearson, G. A. 1920. Factors controlling the distribution of forest types. Ecology 1:129-159, 289-308.

Pearson, G. A. 1931. Forest types in the Southwest as determined by climate and soil. U.S. Dep. Agric. Tech. Bull. 247, 144 p.

Pfister, Robert D. 1972. Vegetation and soils in the subalpine forests of Utah. Ph.D. diss. 98 p. Wash. State Univ., Pullman.

Pfister, Robert D. 1976. Land capability assessment by habitat types. p. 312-325. In America's renewable resource potential-the turning point. Proc. 1975 Natl. Conv. Soc. Am. For., 503 p.

Pfister, R. D., Bernald L. Kovalchik, Stephen F. Arno, and Richard C. Presby. 1977. Forest habitat types of Montana. USDA For. Serv. Gen. Tech. Rep. INT-34, 175 p. + photos and tables. Intermt. For. and Range Exp. Stn., Ogden, Utah.

Poore, M. E. D. 1962. The method of successive approximation in descriptive ecology. Adv. Ecol. Res. 1:35-68.

Pound, R., and F. E. Clements. 1898. The vegetation regions of the prairie province. Bot. Gaz. 25:381-394.

Ream, Robert R. 1963. The vegetation of the Wasatch Mountains, Utah and Idaho. Ph.D. diss. 190 p. Univ. Wis., Madison.

Reed, Robert W. 1971. Aspen forests of the Wind River Mountains, Wyoming. Am. Midl. Nat. 86:327-343.

Reed, Robert W. 1976. Coniferous forest habitat types of the Wind River Mountains, Wyoming. Am. Midl. Nat. 95:159-173.

Rowe, J. S. 1960. Can we find a common platform for the different schools of forest type classification? Silva Fenn. 105:82-105. 
Schubert, Gilbert H. 1974. Silviculture of southwestern ponderosa pine: The status of our knowledge. USDA For. Serv. Res. Pap. RM-123, 71 p. Rocky Mt. For. and Range Exp. Stn., Fort Collins, Colo.

Schubert, Gilbert H., and W. J. Rietveld. 1970. Bristlecone pine-Its phenology, cone maturity and seed production in the San Francisco Peaks, Arizona. USDA For. Serv. Res. Note RM-180, 7 p. Rocky Mt. For. and Range Exp. Stn., Fort Collins, Colo.

Severson, Kieth E., and John F. Thilenius. 1976. Classification of quaking aspen stands in the Black Hills and Bear Lodge Mountains. USDA For. Serv. Res. Pap. RM-166, 24 p. Rocky Mt. For. and Range Exp. Stn., Fort Collins, Colo.

Shreve, F. 1915. The vegetation of a desert mountain range as conditioned by climatic factors. Carnegie Inst. Wash. Publ. 14:84-86.

Shreve, F. 1922. Conditions indirectly affecting vertical distribution on desert mountains. Ecology $3: 269-283$.

Shreve, F. 1942. The vegetation of Arizona. p. 10-23. In Flowering plants and ferns of Arizona. T. Kearney and R. Peebles (eds.) U.S. Dep. Agric. Misc. Publ. 423.

Shiflet, T. N. 1973. Range sites and soils in the United States. p. 26-33. In Arid shrublands. Proc. Third Workshop of the U.S./Australia Panel. Tuscon, Ariz.

Society of American Foresters. 1954. Forest cover types of North America (exclusive of Mexico). Rep. of Comm. on For. Types, Soc. Am. For. 67 p. Wash., D.C.

Spencer, John S., Jr. 1966. Arizona's forests. USDA For. Serv. Resour. Bull. INT-6, 56 p. Intermt. For. and Range Exp. Stn., Ogden, Utah.

Steele, R., R. D. Pfister, Russell A. Ryker, and Jay A. Kittams. 1975. Forest habitat types of central Idaho. U.S. Dep. Agric., For. Serv., Intermt. For. and Range Exp. Stn., 190 p. [Mimeo.]
Steele, R., D. Ondov, S. V. Cooper, and R. D. Pfister. 1977. Preliminary forest habitat types of eastern Idaho and western Wyoming. USDA For. Serv. Intermt. For. and Range Exp. Stn. and Intermt. Reg. 147. p. [Mimeo.]

Tansley, A. G. 1935. The use and abuse of vegetation concepts and terms. Ecology 16:284-307.

Turner, R. M. 1974. Map showing vegetation in the Tucson area, Arizona. USDI Geol. Surv. Misc. Invent. Ser. (Map 1-844-H)

Volland, L. A. 1975. Plant ecology as a land management tool. In Range Multiple Use Management, Wash. State Univ. Coord. Land Use Planning Task Group Rep. 172 p.

Wallmo, O. C. 1955. Vegetation of the Huachuca Mountains, Arizona. Am. Midl. Nat. 54:466-480.

Watson, J. R. 1912. Plant geography of north central New Mexico. Bot. Gaz. 54:194-217.

Westveld, M. 1951. Vegetation mapping as a guide to better silviculture. Ecology 32:508-517.

Whiting, Alfred F. 1942. Junipers of the Flagstaff region. Plateau 15:21-23.

Whittaker, R. H. 1962. Classification of natural communities. Bot. Rev. 28:1-239.

Whittaker, R. H., and W. A. Niering. 1964. Vegetation of the Santa Catalina Mountains, Arizona. I. Ecological classification and distribution of species. Ariz. Acad. Sci. 3:9-34.

Whittaker, R. H., and W. A. Niering. 1975. Vegetation of the Santa Catalina Mountains, Arizona. V. Biomass, production, and diversity along the elevation gradient. Ecology 56:771-790.

Wirsing, J. M., and R. R. Alexander. 1975. Forest habitat types on the Medicine Bow National Forest, southeastern Wyoming: Preliminary report. USDA For. Serv. Gen. Tech. Rep. RM-12, 12 p. Rocky Mt. For. and Range Exp. Stn., Fort Collins, Colo. 